\title{
Antibody-Dependent Enhancement of Viral Infections
}

\author{
Ruta Kulkarni
}

\begin{abstract}
Antiviral antibodies constitute an important component of the host immune response against viral infections and serve to neutralize and reduce infectivity of the virus. However, these antibodies, intended to protect the host, may sometimes prove beneficial to the virus, by facilitating viral entry and replication in the target cell. This phenomenon, known as antibody-dependent enhancement (ADE) of infection, is a result of interaction of virus-antibody immune complexes with Fcy and/or complement receptors on certain types of host cells and promotes viral entry into the host cells. The internalized immune complexes then modulate host immune response so as to enhance viral replication and aggravate disease severity. The possibility of induction of ADE remains a concern in the development and implementation of viral vaccines and immunotherapeutics.
\end{abstract}

\section{Keywords}

Viral infection · Neutralization · Antibody-dependent enhancement · Immune response $\cdot$ Vaccine $\cdot$ Immunotherapeutic

\subsection{Introduction}

Antibody-dependent enhancement (ADE) of infection represents a paradoxical phenomenon in host-pathogen biology, in which, antibody, an important pillar of the host defense against invading pathogen, actually allows entry of the pathogen into host territory. This traitorous behavior of the antibody further serves to weaken the host defense system and thus generates an environment conducive for enhanced

\footnotetext{
R. Kulkarni $(\bowtie)$

Department of Communicable Diseases, Interactive Research School for Health Affairs (IRSHA), Bharati Vidyapeeth (Deemed to be University), Pune, Maharashtra, India
} 
growth of the pathogen and consequently exacerbates disease in the host. This phenomenon has far-reaching implications for disease control and prevention, as therapeutic antibodies deployed to protect the host may aid the pathogen instead. Similarly, antibodies induced by vaccination may actually increase the risk and/or severity of disease in subsequent host-pathogen encounters.

This chapter aims to provide insights into the current knowledge on ADE of viral infections, with a focus on its molecular mechanisms and contribution to viral pathogenesis and disease, as well as implications for disease control strategies.

\subsection{Antibody-Mediated Control of Viral Infections}

Antibodies are an important component of the host adaptive immune response against infecting virus. Virus neutralization is considered to be the key mechanism of antibody-mediated protection. The antiviral activity of antibody is further augmented by Fc-mediated effector mechanisms such as complement-mediated lysis of viral particles, phagocytosis, and antibody-dependent cellular cytotoxicity (ADCC) (Braciale et al. 2013).

Neutralization occurs when antibody molecule(s) bind to the virus particle at its surface epitope and block viral attachment (to cellular receptor) and entry into host cell, and/or post-entry processes such as fusion and uncoating, thus resulting in loss of virion infectivity (Fig. 2.1). Two models have been proposed to describe the kinetics of neutralization. According to the single-hit model, binding of a single antibody molecule to a critical site on the virion is sufficient for neutralization. The more accepted multi-hit model postulates that neutralization can be achieved only when the virion is bound by multiple antibodies, exceeding the stoichiometric threshold of neutralization (Klasse and Sattentau 2002). The potency of neutralization is determined by the affinity of antibody binding and accessibility of the neutralization epitope(s) on the viral surface (Dowd et al. 2011).

\subsection{The Antibody-Dependent Enhancement Phenomenon}

The phenomenon of antibody-dependent enhancement (ADE) was discovered in flaviviruses during the 1960s-1970s. While observational studies on dengue virus (DENV) infections revealed a significant association between severe illness and antibody responses in secondary infection (Halstead et al. 1967), in vitro experiments demonstrated increased infectivity of Murray Valley encephalitis virus (Hawkes 1964; Hawkes and Lafferty 1967) and DENV (Halstead et al. 1973a) in the presence of antibody. In vivo studies in rhesus monkeys showing association of antibody response with higher dengue viremia offered further supportive evidence for this phenomenon (Halstead et al. 1973b; Halstead 1979; Marchette et al. 1973).

ADE ensues when antibodies binding to the virus particle fail to efficiently neutralize the virus (Halstead 2003; Taylor et al. 2015). This may occur due to the nonneutralizing nature of the antibody (binding to viral epitopes other than those 


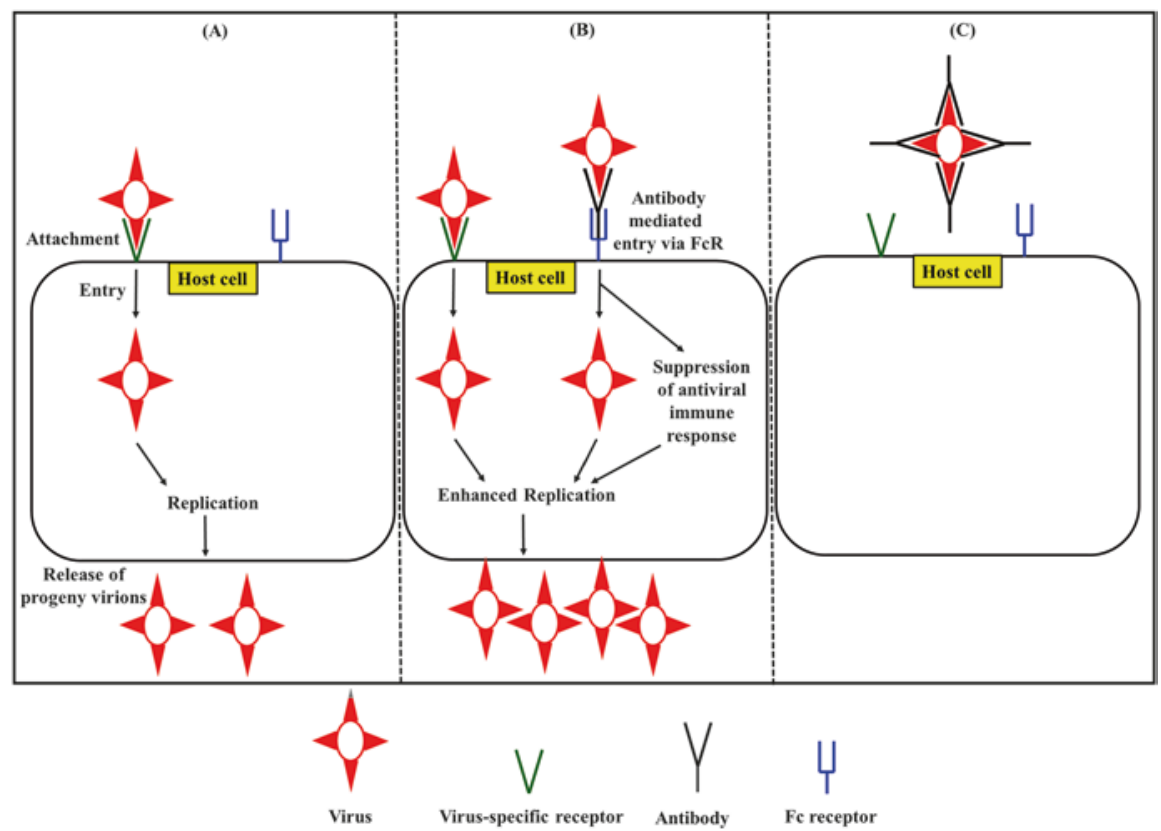

Fig. 2.1 Schematic representation of effect of antibody on virus-host cell interaction. (a) In the absence of virus-specific antibody, virus enters the host cell via interaction with cell surface (virusspecific) receptor, followed by replication and release of progeny virions. (b) In the presence of non-neutralizing or sub-neutralizing concentrations of antibody, an additional pathway of entry into host cell is available to the virus. Virus-antibody immune complexes are internalized via antibody interaction with cell surface $\mathrm{Fc}$ receptor $(\mathrm{FcR})$, resulting in antibody-dependent enhancement (ADE) of viral infection and replication. Internalized immune complexes bring about suppression of cellular innate antiviral immune response further boosting viral replication. (c) In the presence of neutralizing concentrations of antibody, virus attachment and entry into host cell is blocked

involved in cell attachment and entry) or the presence of sub-neutralizing concentrations of antibodies (binding to viral epitopes below the threshold for neutralization). Either way, these antibodies aid entry of the virus into target cells, resulting in enhancement of viral infection, known as antibody-dependent enhancement (Fig. 2.1.). The mechanism of ADE involves internalization of virus-antibody immune complexes into cells via interaction of the antibody Fc region with the cellular Fc receptors (FcRs). Consequently, FcR-bearing myeloid cells such as monocytes, macrophages, dendritic cells, and certain granulocytes are permissive to ADE of infection, through phagocytic uptake of the immune complexes. Such ADE is principally mediated by IgG antibodies, however, IgM along with complement, and IgA antibodies have also been shown to be capable of ADE (Hawkes and Lafferty 1967; Cardosa et al. 1983; Janoff et al. 1995; Kozlowski et al. 1995).

Initially, the role of antibody in enhancing viral infection was believed to be limited to facilitation of virus entry into host cells, resulting in increase in the number of infected cells and, consequently, higher virus production, in a process termed 


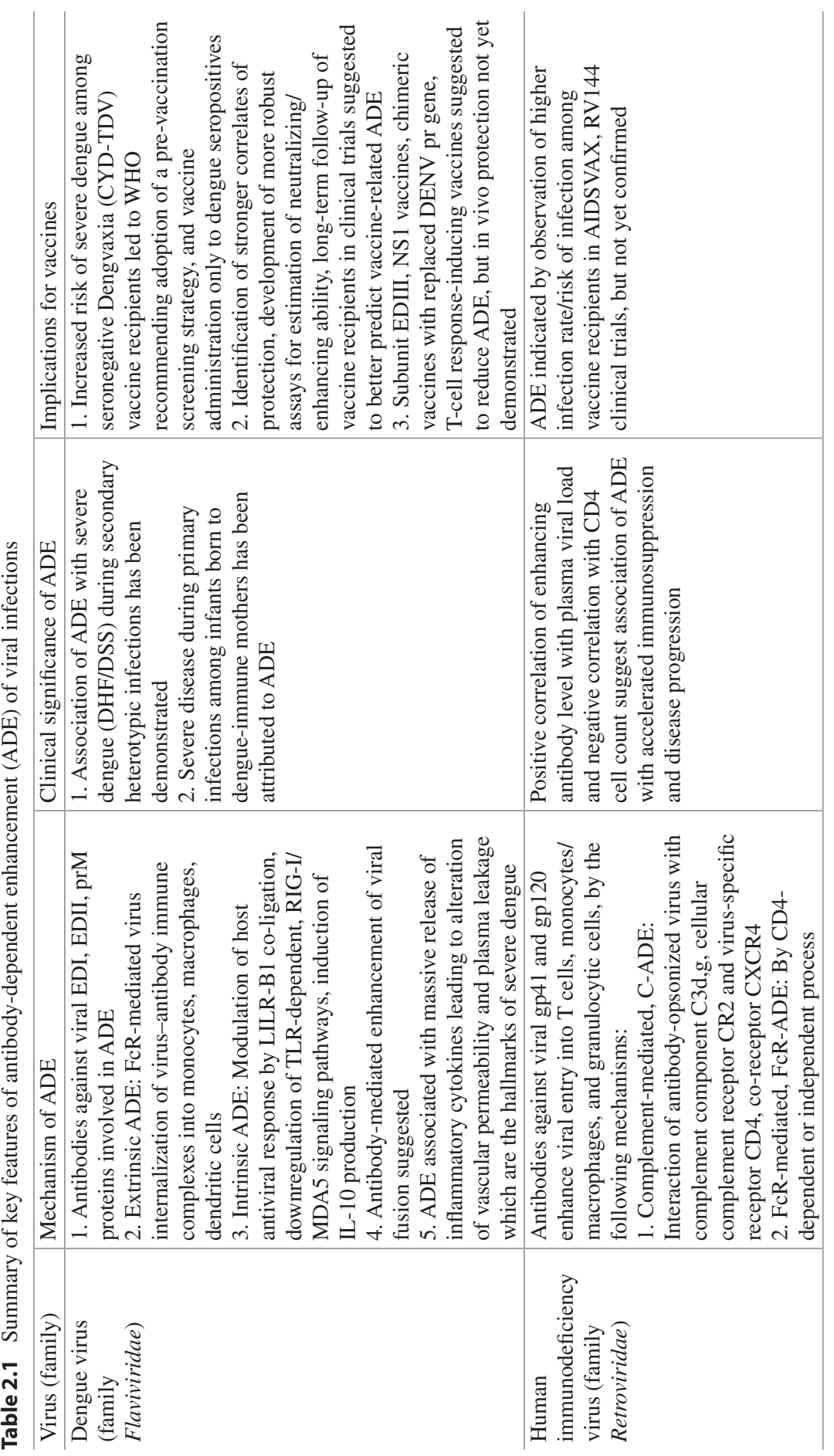




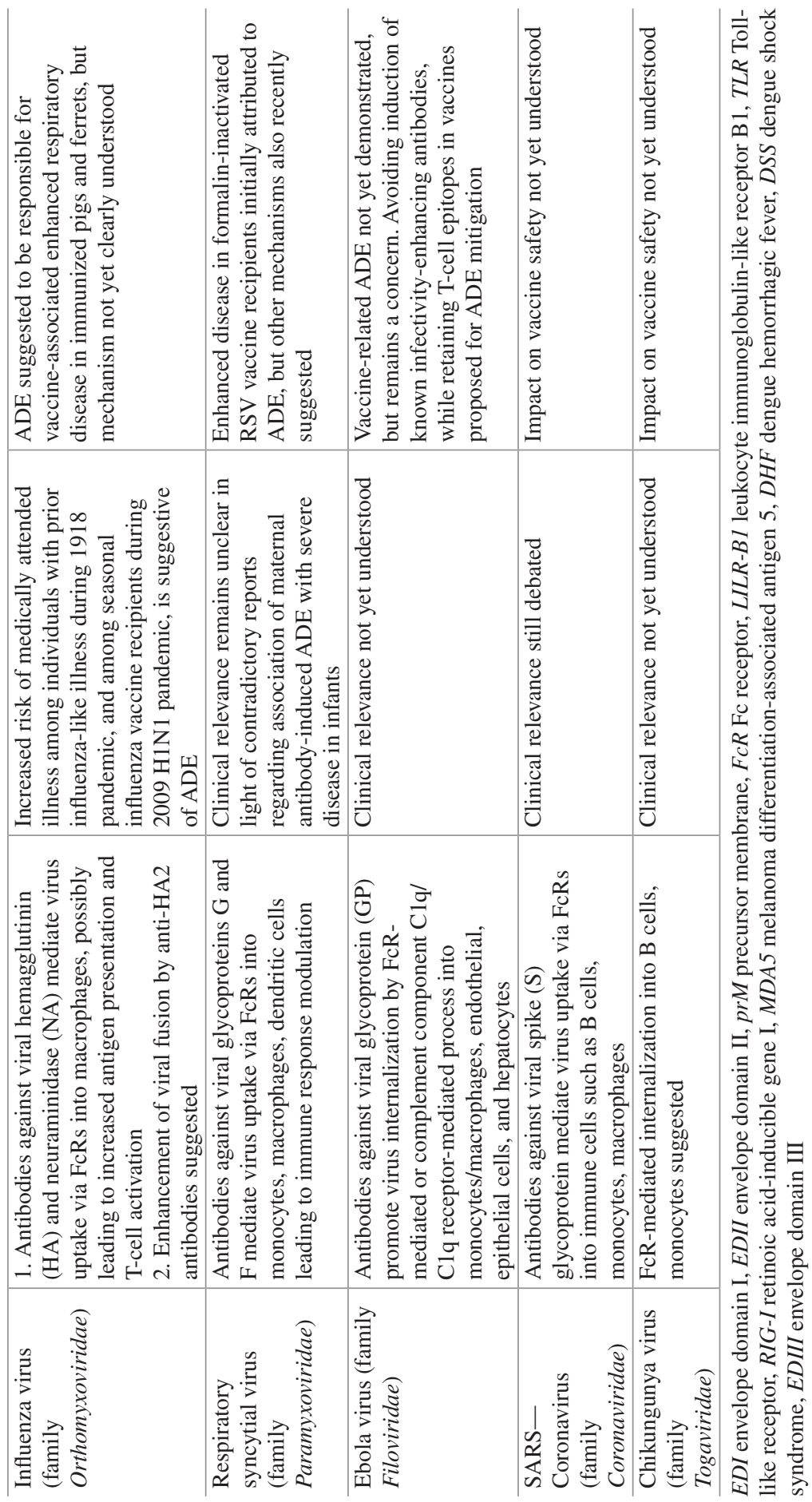


as "extrinsic ADE." However, studies on Ross River Virus suggested that internalized immune complexes further serve to enhance viral replication by suppression of the cellular innate antiviral immune responses (Lidbury and Mahalingam 2000; Suhrbier and La Linn 2003). This mechanism is termed as "intrinsic ADE" and has been subsequently observed in flaviviruses as well (Chareonsirisuthigul et al. 2007; Ubol et al. 2010). Thus, ADE is a complex phenomenon comprising of extrinsic and intrinsic components, which together contribute to augmentation of viral infection and replication. The consequence of this increased virus production is the massive release of inflammatory and vasoactive mediators by host cells, which ultimately leads to exacerbation of viral pathogenesis and disease severity.

Prior sensitization of the humoral immune response is a prerequisite for ADE (Halstead 2003; Taylor et al. 2015). This phenomenon is thus widely observed during secondary infection with a heterotypic virus of the same genus, wherein preexisting antibodies against the primary (sensitizing) infection bind to the (secondary) virus, but fail to neutralize it. The pathogenicity and outcome of secondary infection is influenced by the time interval between primary/secondary infections, with increasing time being associated with more severe disease, and may be explained by the waning of broadly neutralizing antibodies over time. Passively acquired antibodies are also capable of inducing ADE, as indicated by the enhancement of viral disease by preexisting maternal antibody in infants born to dengue-immune mothers (Kliks et al. 1988; Chau et al. 2008, 2009).

The ADE phenomenon has implications for the use of antiviral immunoglobulins as therapy against viral infection, due to the associated risk of enhancement of disease (Taylor et al. 2015). ADE also poses a major challenge for implementation of vaccination programs, as vaccine-induced antibodies may enhance subsequent viral infection, thus placing vaccine recipients at increased risk of severe disease. Indeed, concerns regarding the safety of the world's first licensed dengue vaccine "Dengvaxia" have forced authorities to reconsider the mass vaccination strategy and issue specific recommendations for safe implementation of the vaccine in dengue control programs (Wilder-Smith et al. 2019).

ADE has been exploited by a variety of viruses belonging to different virus families. The mechanism and clinical significance of ADE of selected viruses will be reviewed in this chapter and are also summarized in Table 2.1. The ADE phenomenon has been most extensively studied in dengue virus and will be considered in detail here.

\subsection{Dengue Virus}

Dengue virus (DENV) is a member of family Flaviviridae, genus Flavivirus, and is transmitted to humans through the bite of Aedes mosquitoes, mainly Aedes aegypti. Infection with any of the four serotypes of this virus, DENV-1 to DENV-4, may be asymptomatic, or lead to dengue fever with symptoms ranging from mild to highdegree fever with headache, myalgia, arthralgia, rash, and retro-orbital pain. In some patients, the illness may progress to life-threatening severe dengue [earlier 
classified as dengue hemorrhagic fever (DHF)/dengue shock syndrome (DSS)], characterized by increased vascular permeability, plasma leakage, extensive pleural effusion, severe hemorrhages, respiratory distress, and organ failure (WHO 2009). Dengue disease is endemic in more than 125 countries and is considered a major public health problem worldwide, with an estimated 96 million cases and 20,000 deaths reported annually (Bhatt et al. 2013). In the absence of effective antivirals, dengue treatment mainly relies on symptomatic interventions. Though a licensed vaccine is now available, implementation of mass immunization programs remains complicated due to ADE, and is discussed in later sections.

The DENV genome is a single-stranded, positive-sense RNA molecule $(\sim 11 \mathrm{~kb}$ in size) and contains a single open reading frame coding for a large polyprotein, which is subsequently processed into three structural proteins, capsid (C), membrane (M), and envelope (E), and at least seven nonstructural proteins, NS1, NS2A, NS2B, NS3, NS4A, NS4B, and NS5 (Lindenbach et al. 2013). The E glycoprotein is the major surface-exposed region of the virus and displays the viral antigenic determinants. It functions to bind cellular receptors and fuse with host cell membranes during virus penetration and also directs viral assembly and budding. The $\mathrm{E}$ protein monomer can be divided into three structural/functional domains-EDI, the central region; EDII, the site of fusion; and EDIII, the site of receptor binding (Modis et al. 2004). The M protein is initially expressed as a membrane precursor (prM), which is present in the intracellular immature virus particle. Virion assembly and maturation involves cleavage of the precursor (pr) peptide, resulting in release of the mature virus particle containing the $\mathrm{M}$ protein into the extracellular environment (Li et al. 2008; Junjhon et al. 2010).

\subsubsection{Epidemiological and Experimental Evidence for DENV-ADE}

The possibility of immune enhancement of DENV infection was first suggested by observation of strong association of severe disease (DHF/DSS) with secondary infection among dengue patients in Bangkok, Thailand, during 1962-1964 (Halstead et al. 1967; Guzman et al. 2013). These initial findings were supported by prospective sero-epidemiological studies showing a higher rate of DHF/DSS during secondary infections (Sangkawibha et al. 1984; Graham et al. 1999; Halstead 2008). The association of secondary heterotypic DENV (different serotype) infection with ADE and severe dengue was further strengthened by reports of DHF/DSS cases in Cuba during the 1981/1997 DENV-2 outbreaks and 2001-2002 DENV 3 outbreak in a population immune to DENV-1 (1981/1997) and DENV-1/2 (2001-02), respectively (Guzman et al. 1990, 2000; Alvarez et al. 2006). Further, it has been demonstrated that such secondary DHF/DSS cases have higher viremia and levels of pro-inflammatory cytokines, suggesting that greater infected cell mass and subsequent increase in cytokine release contribute to disease severity in these patients (Vaughn et al. 2000; Wang et al. 2006; Rothman 2011). However, interestingly, tertiary/quaternary DENV infections have been rarely associated with severe 
disease, presumably due to sufficient cross-protective immunity acquired after two (primary/secondary) different DENV infections (Gibbons et al. 2007).

The most compelling evidence for ADE is provided by observation of severe dengue during primary infection in infants born to dengue-immune mothers (Kliks et al. 1988; Chau et al. 2008, 2009). During the first 3-4 months after birth, passively acquired maternal antibodies have been shown to protect infants from symptomatic dengue. Thereafter, the maternal antibodies begin to decline and reach sub-neutralizing levels, at which the antibodies are capable of enhancing DENV infection. Such enhancing antibodies persist till $\sim 12$ months of age, placing the infants at increased risk of severe dengue. Indeed, this enhancing activity of the infant sera has been demonstrated in vitro.

DENV-ADE is supported extensively through in vitro experiments. Enhancement of DENV infection by anti-DENV monoclonal antibodies or polyclonal human immune sera has been observed in primary human myeloid cells as well as cell lines such as Fc $\gamma$ R-expressing BHK-21 cells, monocytic U937, THP-1, K562 cells, and macrophage-like P388D1 cells (Halstead et al. 1973a; Morens et al. 1987; Cardosa 1987; Kliks 1990; Goncalvez et al. 2007; Moi et al. 2013; Guzman et al. 2013; Acosta and Bartenschlager 2016). Moreover, in vitro ADE by human sera has been associated with severe dengue in patients. The ADE phenomenon has also been demonstrated in animal studies, with higher viremia being recorded during experimental secondary infection in rhesus monkeys as well as in passively immunized monkeys (Halstead et al. 1973b; Halstead 1979; Marchette et al. 1973; Goncalvez et al. 2007). Further, DENV-specific antibodies have been shown to enhance DENV infection and disease severity in AG129 mouse model (Zellweger et al. 2010). In another study using AG129 mice, maternally acquired anti-DENV antibodies were found to enhance viremia and vascular leakage, leading to earlier death (Ng et al. 2014).

The ultimate verification for DENV-ADE in humans has been provided only recently in a long-term pediatric cohort study in dengue-endemic Nicaragua (Katzelnick et al. 2017). This study observed highest risk for severe dengue among individuals with suboptimal anti-DENV antibody titers, and protection from symptomatic dengue at high antibody titers, thus proving that the level of preexisting anti-DENV antibodies is directly associated with the severity of secondary dengue disease in humans.

\subsubsection{Molecular Mechanism of DENV-ADE}

\subsubsection{Antibodies Enhancing DENV Infection}

Studies using monoclonal antibodies obtained from primary/secondary dengue patients have identified DENV surface proteins E and prM as major targets of host immune response (Serafin and Aaskov 2001; Crill and Chang 2004; Beltramello et al. 2010; Matsui et al. 2010; Wahala and Silva 2011; Fibriansah et al. 2015; Gan et al. 2017). These studies have suggested that highly neutralizing antibodies are predominantly raised against the complex quaternary epitopes of the viral envelope 
and the EDIII (lateral ridge) region involved in cellular attachment. These antibodies are mostly serotype-specific; however, antibodies raised against the quaternary "envelope dimer epitope" (EDE) have been found to potently neutralize all four DENV serotypes (Dejnirattisai et al. 2015). Such protective antibodies represent only a small subset of the antibody repertoire in dengue patients, with the immune response being dominated by cross-reactive, non-neutralizing antibodies targeting EDI, EDII (fusion loop) and prM, which have the potential to enhance viral infection (Smith et al. 2014). Moreover, all neutralizing antibodies are also capable of enhancing infection when present at sub-neutralizing concentration.

The role of antibodies against prM protein is particularly important because of its ability to enhance infection of immature virions, which are otherwise noninfectious. The prM protein, present in the intracellular immature virus particle, covers the fusion domain of the E protein, thus preventing its fusion with the host cell membrane. Cleavage of the precursor (pr) peptide from the prM protein during the process of virus maturation renders the released mature virus particle "infectious" to host cells for further rounds of replication (Li et al. 2008; Junjhon et al. 2010). Inefficient processing of the prM protein results in the production of immature or partially immature virus particles, which are normally noninfectious due to their inability to fuse with host cell. However, studies using human monoclonal antibodies obtained from persons with secondary dengue have revealed that these immature virus particles are capable of infecting host cells in the presence of the nonneutralizing anti-prM antibodies, and are thus infectious during secondary infections with the possibility of contributing to severe disease (Dejnirattisai et al. 2010; Schmidt 2010). Similarly, antibodies specific to the fusion loop (FL) in EDII have also been shown to enhance the infectivity of immature DENV particles (RodenhuisZybert et al. 2011).

\subsubsection{Fcy Receptors and Their Role in ADE}

The Fc $\gamma$ receptors (Fc $\gamma \mathrm{Rs})$ present on the surface of cells of the myeloid lineage function to internalize antibody-opsonized virus via receptor-mediated endocytosis or phagocytosis and thus aid in clearance of the virus from blood circulation. However, these Fc $\gamma$ Rs can also contribute to ADE of DENV infection, by offering the virus an alternative pathway of entry into its target cells, the Fc $\gamma \mathrm{R}$-bearing monocytes, macrophages, and dendritic cells (Taylor et al. 2015; Gan et al. 2017). There are three classes of human Fc $\gamma$ Rs, namely, Fc $\gamma$ RI, Fc $\gamma$ RII, and Fc $\gamma$ RIII. Fc $\gamma$ RI is a high-affinity activating receptor that can bind to monomeric IgG molecules (Vogelpoel et al. 2015). FcyRII is a class of low-affinity receptors that require high avidity binding by IgG immune complexes. Of these, Fc $\gamma$ RIIA and Fc $\gamma$ RIIC are activating receptors, while Fc $\gamma$ RIIB is an inhibitory receptor (Guilliams et al. 2014). The activating receptors are involved in intracellular signal transduction via the immunoreceptor tyrosine-based activation motif (ITAM), either accessory (for Fc $\gamma R I$ ) or present within the receptor cytoplasmic domain (for Fc $\gamma$ RIIA), while the inhibitory receptor contains immunoreceptor tyrosine-based inhibitory motif (ITIM) in its cytoplasmic domain (Boonnak et al. 2013). Activating receptors efficiently internalize antibody-opsonized virus, and can be involved in neutralization 
or enhancement, depending on the antibody concentration and receptor properties. Fc $\gamma$ RI being a high-affinity receptor requires significantly less antibody for complete neutralization and thus plays a predominant role in DENV neutralization (Chawla et al. 2013). In contrast, Fc $\gamma$ RIIA has been shown to be an effective mediator of ADE, with its ITAM-containing cytoplasmic tail playing a crucial role (Boonnak et al. 2013).

The monocytes, which are the major site of DENV infection and replication, express Fc $\gamma$ RI and Fc $\gamma$ RIIA at high levels and Fc $\gamma$ RIIB at intermediate levels. FcyRIII is expressed on only $\sim 10 \%$ of the monocyte population and has little impact on DENV neutralization or enhancement (van de Winkel and Anderson 1991). Macrophages express Fc $\gamma$ RI, Fc $\gamma$ RII, and Fc $\gamma$ RIII. Dendritic cells express Fc $\gamma$ RIIA and Fc $\gamma$ RIIB, but Fc $\gamma$ RIIB decreases with maturity (Guilliams et al. 2014).

\subsubsection{Antibody-Mediated Viral Entry into Target Cell}

Cells of the mononuclear phagocyte lineage, like monocytes, macrophages, and dendritic cells, are the main targets for DENV infection in humans. Attachment of DENV E protein (EDIII) to putative cell surface receptors such as heparan sulfate, C-type lectins, heat shock protein 70/90, and phosphatidylserine receptors constitutes the first step of viral infection (Castilla et al. 2015; Cruz-Oliveira et al. 2015). This is followed by penetration of the host cell by receptor-dependent, clathrin- and dynamin-mediated endocytic pathway. Acidic $\mathrm{pH}$ of the endocytic vesicle then triggers fusion of the viral envelope with the endosomal membrane, thus facilitating virion uncoating and release of the viral genome into the cellular cytoplasm.

During ADE, the antibody-opsonized DENV binds to the FcyRs present on the surface of the target cells and is internalized by Fc $\gamma$ R-mediated endocytosis/phagocytosis. The entry pathway is similar to that of free virus; however, it shows slight alterations, depending on the cell type as well as the Fc $\gamma \mathrm{R}$ engaged. In vitro studies in monocytic cell lines U937 and K562 have shown that Fc $\gamma$ RII-mediated entry occurs through clathrin-coated vesicles, while Fc $\gamma$ RI-mediated entry is clathrinindependent. Also, as Fc $\gamma$ RII translocates into lipid rafts upon immune complex binding, entry via this receptor is affected by the membrane cholesterol content (Carro et al. 2018). In macrophage-like P388D1 cells, antibody-opsonized virus is shown to be internalized by phagocytic uptake facilitated by actin-mediated membrane protrusions which actively search and capture the antibody-bound virus particles, possible by chemotaxis (Ayala-Nunez et al. 2016).

In addition to $\mathrm{Fc} \gamma \mathrm{R}$, other primary cell receptors may also be required for cell penetration. In fact, one theory suggests that $\mathrm{Fc} \gamma \mathrm{R}$ plays an auxiliary role in concentrating the immune complexes to the cell surface and viral entry is then mediated by the primary cellular receptors (Chotiwan et al. 2014).

\subsubsection{Suppression of Innate Antiviral Immune Response in ADE}

The suppression of the host antiviral immune response to facilitate higher virus production during ADE of DENV infection was first suggested in 2007 through studies in monocytic THP-1 cells, which revealed upregulation of anti-inflammatory cytokine production (IL-6, IL-10) but downregulation of anti-DENV free radicals (nitric 
oxide) and pro-inflammatory cytokine production (IL-12, IFN- $\gamma$, TNF- $\alpha$ ) (Chareonsirisuthigul et al. 2007). Subsequent studies in THP-1 cells offered further insights into the mechanism of this "intrinsic" DENV-ADE (Ubol et al. 2010; Modhiran et al. 2010; Tsai et al. 2014; Chan et al. 2014). Overall, these studies have suggested Type I interferon and pro-inflammatory cytokine production as the main targets of immune suppression during DENV-ADE, with four mechanisms being proposed for the same: (1) leukocyte immunoglobulin-like receptor B1 (LILR-B1) coligation and consequent inhibition of Fc $\gamma \mathrm{R}$-signaling and Type I interferon-stimulated gene (ISG) expression, (2) downregulation of toll-like receptor (TLR)-dependent antiviral signaling pathway, (3) downregulation of retinoic acid-inducible gene I (RIG-I)/melanoma differentiation-associated antigen 5 (MDA-5) signaling pathway resulting in suppression of Type I interferon (IFN) production, and (4) induction of IL-10 production resulting in suppressor of cytokine signaling 3 (SOCS3)-mediated suppression of pro-inflammatory cytokines important for antiviral response.

Binding of immune complexes to cellular activating FcyRs is known to trigger ITAM-spleen tyrosine kinase (Syk)-signal transducer and activator of transcription 1 (STAT1) signaling pathway which leads to ISG induction and inhibition of viral replication. Inhibition of this Fc $\gamma \mathrm{R}$-dependent ISG transcription is thus crucial for successful DENV replication and is proposed to be brought about by co-ligation of LILR-B1 by the FcyR-bound antibody-opsonized DENV (Chan et al. 2014; Nimmerjahn and Lux 2014). LILR-B1 belongs to a family of ITIM-containing inhibitory receptors and is expressed on immune effector cells including monocytes, macrophages, and dendritic cells. At sub-neutralizing antibody concentrations, the DENV-antibody immune complex binds to two cellular receptors: Fc $\gamma \mathrm{R}$ (through antibody) and LILR-B1 (through DENV E protein). Binding to LILR-B1 recruits Src homology phosphatase-1 (SHP-1) which dephosphorylates and inactivates Syk and prevents ISG expression. SHP-1 signaling also prevents rapid acidification and lysosomal degradation of DENV (Ong et al. 2017). On the contrary, at high antibody concentrations, DENV E protein epitopes are completely blocked by the antibody; consequently, LILR-B1 binding is not possible, resulting in neutralization of the Fc $\gamma \mathrm{R}$-internalized virus.

The TLR-dependent pathway is a key mediator of the innate antiviral immune response and stimulates production of Type I IFN and pro-inflammatory cytokines via nuclear factor- $\kappa \beta$ (NF- $\kappa \beta)$ family of transcription factors. Studies using monocytic cell lines and patient peripheral blood mononuclear cells (PBMCs) have shown that this pathway is suppressed during DENV-ADE (Modhiran et al. 2010). Engagement of FcR by DENV-antibody immune complexes or FcR-mediated entry of immune complexes into target cells results in downregulation of expression of TLR-3,-4,-7 and TLR signaling molecules. This is accompanied by activation of Sterile-alpha and Armadillo motif-containing protein (SARM) and TRAF family member-associated $\mathrm{NF}-\kappa \beta$ activator (TANK), which are negative regulators of the TLR adaptor molecule, TIR-domain-containing adapter-inducing interferon- $\beta$ (TRIF), and effector molecule, TNF receptor-associated factor 6 (TRAF6), respectively. SARM/TANK activation thus results in suppression of TLR-dependent IFN stimulating pathway. 
The RIG-I/MDA-5 antiviral signaling pathway is also downregulated during DENV-ADE, as demonstrated in vitro and observed among patients of severe secondary DENV infection (Ubol et al. 2010). Entry of immune complexes into target cells activates the negative regulators, dihydroxyacetone kinase (DAK) and autophagy-related 5-autophagy-related $12(\operatorname{Atg} 5-\operatorname{Atg} 12)$, which then disrupt the RIG-I/MDA-5 signaling cascade. This results in suppression of Type I IFN production and IFN-mediated antiviral responses.

IL-10 is known to induce T-helper cell 2 (Th2) cytokine response and inhibit production of pro-inflammatory cytokines such as IFN- $\gamma, \mathrm{IL}-12, \mathrm{TNF}-\alpha$ as well as nitric oxide radicals, which are potent inhibitors of DENV replication. IL-10 induction during DENV-ADE thus exerts an immunosuppressive effect and favors viral replication. Indeed, high IL-10 levels have been associated with severe disease in secondary dengue patients (Nguyen et al. 2004; Ubol et al. 2010). The mechanism of IL-10-mediated immune suppression has been demonstrated through in vitro studies in monocytic cell lines and patient PBMCs. These studies have shown that IL-10 induction during ADE occurs through enhanced Syk-regulated phosphoinositide 3-kinase (PI3K)/protein kinase B (PKB)/glycogen synthase kinase (GSK)-3 $\beta /$ cyclic adenosine monophosphate response element-binding (CREB) signaling (Tsai et al. 2014). IL-10 then stimulates expression of SOCS3, which subsequently inactivates Janus kinase (Jak)-STAT signaling, resulting in suppression of pro-inflammatory cytokine production. In addition, IL-10 also suppresses inducible nitric oxide synthase (iNOS) gene expression and thus nitric oxide production, by inhibiting STAT-1 and Interferon Regulatory Factor 1 (IRF-1) activity (Chareonsirisuthigul et al. 2007; Ubol et al. 2010).

Majority of the studies elucidating the mechanism of intrinsic ADE have been carried out in monocytic cell lines. Experiments using primary monocyte-derived human macrophages have demonstrated lower IFN- $\beta$ and higher IL- 6 and SOCS3 levels during DENV-ADE, consistent with the observations in monocytic cells (Rolph et al. 2011). However, IL-10 induction and RIG-I/MDA-5 downregulation were not observed. Thus, IL-6 has been proposed as critical regulator of DENVADE in macrophages, responsible for SOCS-3-mediated suppression of proinflammatory cytokines, indicating that mechanisms of intrinsic ADE may be cell type-dependent.

Contradictory to the well-accepted mechanism of ADE-mediated immune suppression, a recent study observed that entry of DENV immune complexes in primary human macrophages did not trigger immunosuppressive signaling, but resulted in enhanced fusion of viral envelope with the host cell membrane (Flipse et al. 2016). Further investigations into the different mechanisms involved in ADE of DENV infection are thus warranted.

\subsubsection{Enhancement of Disease Severity: ADE and Cytokine Storm}

The extrinsic and intrinsic mechanisms of ADE together contribute to enhancement of viral replication and consequently higher viremia levels, which correlate with the incidence of severe dengue in patients (Vaughn et al. 2000). ADE is also associated with triggering of the "cytokine storm" which involves massive release of 
inflammatory cytokines and other chemical mediators at high levels (Pang et al. 2007). ADE of DENV infection and replication results in increased presentation of viral antigens on the surface of infected cells, leading to activation and proliferation of $\mathrm{T}$ cells sensitized during a prior infection. This results in release of cytokines such as IFN- $\gamma$, TNF- $\alpha$, IL-2, IL-6, IL1- $\beta$, IL-8 and immunoregulators such as IL-12p70, which directly act upon the vascular endothelial cells resulting in plasma leakage, the hallmark of severe dengue. Increased levels of such cytokines have been associated with plasma leakage in severe dengue patients (Chaturvedi et al. 2000), while effect of the cytokine response on alteration of vascular permeability has been demonstrated in vitro and in mice models, with disruption of the apical junction complexes in endothelial cells being the suggested mechanism (Dewi et al. 2004; Appanna et al. 2012; Puerta-Guardo et al. 2013).

\subsubsection{Implications for Dengue Vaccines}

Generation of a long-term protective immune response against all four serotypes of DENV is a prerequisite for a dengue vaccine and assumes greater importance due to the associated risk of vaccine-induced ADE of DENV infection and disease. During the six-decade long quest for an effective dengue vaccine, several candidates such as live-attenuated, inactivated, recombinant subunit, virus-like particle (VLP)based, and DNA vaccines have been explored, with Sanofi Pasteur's "Dengvaxia" or CYD-TDV, a chimeric yellow fever 17D-tetravalent DENV vaccine, National Institutes of Health's TV003/TV005, and Takeda Pharmaceutical's TAK-003, both live attenuated tetravalent vaccines, leading the development pipeline (McArthur et al. 2013). Of these, CYD-TDV has been approved for human use and is licensed in 20 countries, while TV003/TV005 and TAK-003 are currently undergoing Phase III trials.

CYD-TDV, the world's first licensed dengue vaccine, was approved by the World Health Organization (WHO) in May 2016, following Phase III trials in dengueendemic regions (Capeding et al. 2014; Villar et al. 2015; Hadinegoro et al. 2015). These trials had demonstrated high vaccine efficacy among 9-16-year-olds during the first 2 years after vaccine (first of three doses) administration, but indicated increased risk of hospitalized dengue in the 2-5 year age group during the third year of follow-up. These results suggested the possibility of the vaccine sensitizing dengue seronegatives to subsequent enhanced DENV infection and disease. However, considering the population-level benefits in reducing disease burden, the vaccine was approved by WHO Strategic Advisory Group of Experts (SAGE) on immunization, with recommendations for use in dengue-endemic regions with $\geq 70 \%$ seroprevalence and administration to individuals in the age range of 9-45 years. This approval was followed by additional studies to investigate the long-term benefitrisk ratio of dengue vaccination in seronegative population. These studies revealed that vaccine performance was indeed affected by serostatus, with vaccine efficacy being significantly higher in seropositives than seronegatives. Furthermore, an increased risk of hospitalized, severe dengue was observed among seronegative 
vaccine recipients as compared to seronegative controls (Sridhar et al. 2018). In light of this new evidence regarding vaccine-related ADE, WHO-SAGE issued updated recommendations on the use of CYD-TDV vaccine in April 2018 (WilderSmith et al. 2019). For countries considering vaccination as part of their dengue control program, WHO now recommends a "pre-vaccination screening strategy," in which all potential vaccine recipients are tested for anti-DENV IgG, preferably by ELISA, and only dengue-seropositive persons are vaccinated. Further, for trials of new vaccines, WHO advises stratification of participants according to pre-vaccination serostatus during data analysis, as well as long-term follow-up of all vaccine recipients.

The occurrence of breakthrough infections in the CYD-TDV vaccinees despite having high titers of neutralizing antibodies has raised concerns regarding the value of the currently used in vitro neutralization tests as correlates of protection. The neutralizing potential of antibodies is commonly evaluated using the plaque reduction neutralization test (PRNT) in LLC-MK2, Vero, or BHK-21 cell lines. However, neutralization of DENV infection in these Fc $\gamma \mathrm{R}$-negative cells may not reflect the ability of the antibodies to prevent infection of myeloid cells, which are primary targets of DENV, and capable of internalizing antibody-opsonized DENV through Fc $\gamma$ R-mediated phagocytosis. The use of FcyR-bearing cell lines or primary myeloid cells for in vitro neutralization has thus been proposed for measuring the neutralizing versus enhancing ability of anti-DENV antibodies (Mahalingam et al. 2013; Gan et al. 2017). Furthermore, identification of stronger immune correlates for disease risk and protection is urgently needed (Katzelnick and Harris 2017).

While the results of Phase III trials of TV003/TV005 and TAK-003 vaccines are awaited, the concern of vaccine-related ADE has promoted development of vaccines specifically designed to minimize ADE. Monoclonal antibody-based studies have helped identify neutralizing and enhancing viral epitopes, making design of such tailored vaccines possible. DENV EDIII induces predominantly neutralizing antibodies, thus making recombinant EDIII an attractive subunit vaccine candidate (Gil et al. 2017; Frei et al. 2018). DENV NS1 has also been considered as a vaccine candidate as it avoids ADE (Hertz et al. 2017). Chimeric DENV constructs with pr gene replaced with Japanese Encephalitis virus pr and DNA vaccines with substitutions or removal of enhancing epitopes have demonstrated reduction in ADE (Crill et al. 2012; Tang et al. 2015; Wang et al. 2015). Another strategy for evasion of ADE is the development of vaccine candidates inducing protective CD4+ and CD8+ T-cell responses. DENV $\mathrm{C}$ protein is an immunodominant $\mathrm{T}$-cell epitope, and $\mathrm{C}$-based vaccines have shown induction of protective T-cell-mediated immunity in monkeys (Gil et al. 2014). Such next-generation vaccines do face the disadvantage of not retaining the intact virion structure and the quaternary epitopes, which are important for potent neutralization. However, these vaccines have shown encouraging results in preclinical studies, and whether they are capable of conferring in vivo protection remains to be seen. 


\subsubsection{Implications for Dengue Therapeutics}

Humanized monoclonal antibodies (mAbs) are attractive therapeutic options against DENV infection. Therapeutic mAbs must neutralize DENV, without increasing the risk of ADE, in order to offer protection against dengue. Several mAbs targeting the DENV E and/or prM proteins are being developed as therapeutic candidates, with reduction of ADE as the major focus of development (Chan et al. 2013; Sun et al. 2018). Use of serotype-specific mAbs or high dose administration of cross-reactive $\mathrm{mAbs}$ has demonstrated reduced risk of ADE in vitro and in animal models. Further, antibodies with modifications in the $\mathrm{Fc}$ region such as deletion of nine amino acids (at positions 231-239) in the $\mathrm{N}$ terminus, mutation of asparagine to glutamine at position 297 (N297Q), or mutation of leucine to alanine at positions 234 and 235 (LALA mutants) have also shown reduced risk of ADE and exhibited prophylactic and therapeutic efficacy in animal models (Balsitis et al. 2010; Shi et al. 2016; Xu et al. 2017; Injampa et al. 2017; Lu et al. 2018). Fc region modifications that extend the antibody half-life also help minimize ADE by maintaining the mAbs at high levels.

\subsubsection{ADE in Other Flaviviruses}

ADE has also been reported in other viruses of family Flaviviridae including Murray Valley Encephalitis virus, Japanese encephalitis virus (JEV), West Nile virus (WNV), yellow fever virus (YFV), and Zika virus (ZIKV) of genus Flavivirus, as well as hepatitis $\mathrm{C}$ virus (HCV), of genus Hepacivirus (Hawkes and Lafferty 1967; Cardosa et al. 1983; Gould and Buckley 1989; Meyer et al. 2008; Bardina et al. 2017). Further, infection with one Flavivirus has also been demonstrated to enhance subsequent infection with another virus of the same genus, as observed for DENV-ZIKV in in vitro studies, mice models, and rhesus macaques (Bardina et al. 2017; George et al. 2017). Such DENV-ZIKV cross-enhancement has also been observed in primary human PBMCs ( $\mathrm{Li}$ et al. 2018); however, in the absence of clinical or epidemiological evidence, the clinical relevance of these findings is unknown. Interestingly, a beneficial effect of cross-enhancement among flaviviruses has been reported recently in a clinical trial, with preexisting JEV vaccine-induced antibodies enhancing immunogenicity of subsequently administered YFV vaccine (Chan et al. 2016).

\subsection{Human Immunodeficiency Virus}

Human immunodeficiency virus (HIV), a member of family Retroviridae, genus Lentivirus, is primarily a sexually transmitted virus, but nonsexual transmission through intravenous inoculation or mother-to-child exposure can also occur. HIV infects the CD4+ T cells leading to their progressive depletion and thus hampers the host adaptive immune response. The final stage of HIV infection is acquired 
immunodeficiency syndrome (AIDS), characterized by immune system failure and occurrence of life-threatening opportunistic infections. As of 2016, 37 million people worldwide have been estimated to be living with HIV (Ghosn et al. 2018). While a protective vaccine or a complete cure of HIV infection remains elusive, implementation of combination antiretroviral therapy (cART) has been successful in prolonging the duration between HIV infection and AIDS and reducing AIDSrelated deaths.

\subsubsection{ADE of HIV Infection: Experimental Evidence and Molecular Mechanism}

ADE of HIV infection was first reported in the 1980s, shortly after the identification and isolation of HIV, and two different mechanisms, namely, complement-mediated ADE (C-ADE) (Robinson Jr. et al. 1987, 1988) and FcR-mediated ADE (FcR-ADE) (Takeda et al. 1988; Homsy et al. 1989), were described. Through either of these mechanisms, virus-specific antibodies present in sera of HIV-infected individuals were shown to enhance viral entry and in some cases replication within $\mathrm{T}$ cells, monocytes/macrophages, and granulocytic cells (Beck et al. 2008). Further, both these mechanisms have also been shown to enhance HIV infection of human syncytiotrophoblast cells, thus suggesting contribution of ADE to materno-fetal transmission (Tóth et al. 1994). Both these forms of ADE are mediated by antibodies targeting the viral surface glycoproteins gp41 and gp120 (Trischmann et al. 1995; Takada and Kawaoka 2003). Such enhancing antibodies have been detected in $72 \%$ of HIV patients (Subbramanian et al. 2002).

$\mathrm{C}$-ADE of HIV infection has been well characterized through in vitro studies in T-cell lines such as MT-2 and SupT1/R5, showing enhancement of cell line-adapted HIV strains or primary virus isolates by human monoclonal antibodies or sera from HIV-infected individuals, and has been associated with increased synthesis of viral RNA and protein and enhanced release of infectious virions (Robinson Jr. et al. 1989, 1990a, b; Robinson Jr. 2006; Willey et al. 2011). Such C-ADE is primarily mediated by antibodies targeting the $\mathrm{N}$-terminal immunodominant domain of viral gp41. Antibody binding to gp41 initiates the complement cascade leading to deposition of complement component $\mathrm{C} 3 \mathrm{~d}, \mathrm{~g}$ on the virion. Interaction of this opsonized virus with the cell surface complement receptor type 2 (CR2) facilitates virus attachment and internalization. Engagement of the HIV receptor CD4 and coreceptor CXCR4 is also required for this mode of virus uptake. Increased attachment of the virus to target cell, rather than CR2-mediated signaling, has been suggested to be responsible for enhancement of infection through C-ADE. An alternative route of complement component $\mathrm{C} 1 \mathrm{q}$ binding followed by interaction with C1q receptor has also been suggested for C-ADE (Prohaszka et al. 1997).

FcR-ADE has been demonstrated in vitro mainly in monocyte/macrophage cell lines and primary cultures, with all three classes of Fc $\gamma$ R, namely, Fc $\gamma$ RI, Fc $\gamma$ RII, and Fc $\gamma$ RIII, reported to support ADE (Homsy et al. 1989; Takeda et al. 1988, 1990; Laurence et al. 1990; Connor et al. 1991; Trischmann et al. 1995). ADE by Fc $\gamma$ RI 
and FcyRII requires viral interaction with CD4, indicating that the FcRs facilitate virus entry by potentiating attachment to CD4 receptors. Alternatively, FcRmediated endocytosis of virus-antibody complexes followed by intracellular fusion with endosomal membrane occurring as a result of binding of virus with CD4 receptors on the endosomal membranes has also been suggested. FcyRIII-mediated ADE has been shown to be CD4-independent. FcR-ADE assumes particular importance in the viral life cycle as it mediates infection of macrophages, which are important for maintaining a viral reservoir during persistent infections.

Another mechanism of complement-independent, FcR-independent ADE, mediated by antibodies specific to viral gp120, has been described (Sullivan et al. 1998; Guillon et al. 2002). Antibody binding has been shown to modulate interaction of gp120 with HIV co-receptor CCR5 or induce conformational changes in gp120, leading to its activation and subsequent promotion of membrane fusion. Further, Fc $\alpha$ R-mediated ADE has also been reported, with human serum IgA showing low-level enhancement of HIV replication in vitro (Janoff et al. 1995; Kozlowski et al. 1995).

An important feature of HIV is the rapid viral evolution during chronic infection. While neutralizing antibodies are known to exert a selection pressure facilitating emergence of neutralization escape mutants, enhancing antibodies have been suggested to favor emergence of ADE-susceptible variants. Indeed, at later stages of infection, patient sera have demonstrated increased proportion of enhancing antibodies and potential for ADE, while virus strains isolated at such later stage have exhibited increased susceptibility to ADE in vitro (Davis et al. 2001; Subbramanian et al. 2002; Willey et al. 2011).

\subsubsection{Clinical Significance of HIV-ADE}

The HIV disease outcome is suggested to be influenced by the balance of neutralizing and enhancing antibodies in HIV patients, with studies showing lower neutralizing and higher enhancing antibody levels among AIDS patients (Homsy et al. 1990; Toth et al. 1991; Fust et al. 1994; Szabo et al. 1999; Subbramanian et al. 2002). These studies have observed strong negative correlation between the extent of ADE and CD4 cell count and positive correlation between ADE and plasma viral load in HIV-positive individuals. As CD4 cell count and HIV plasma viral load are considered the most potent predictors of HIV disease progression, such observations indicate contribution of ADE to accelerated immunosuppression and disease progression. Further support for this association was provided by reports of decline in enhancing antibody levels and improvement in disease prognosis in patients receiving highly active antiretroviral therapy (HAART) (Banhegyi et al. 2003). Contradictory observations of absence of any clinical correlation between ADE and disease have also been reported (Montefiori et al. 1991); however, it has been suggested to be the result of conduction of experiments in conditions which do not sufficiently resemble in vivo conditions (Takada and Kawaoka 2003; Beck et al. 2008). 


\subsubsection{Implications for HIV Vaccines}

The impact of ADE on HIV vaccine safety is not clearly understood. Studies in Rhesus monkeys have demonstrated the association of active and passive immunization with enhanced disease progression on subsequent infection (Staprans et al. 2004; Sholukh et al. 2014). In humans, ADE has been indicated in two vaccine clinical trials. In the AIDSVAX trial, the rate of HIV infection was observed to be higher among vaccinees with low (non-protective) antibody responses (Gilbert et al. 2005). In the RV144 trial, positive correlation of vaccine-elicited plasma IgA responses with risk for HIV acquisition was documented (Shmelkov et al. 2014). Further, a study investigating the effect of passive immunization of HIV-positive pregnant women on mother-to-infant transmission suggested the possibility of antibody-enhanced in utero transmission (Onyango-Makumbi et al. 2011). These findings are suggestive of vaccine-induced ADE, but cannot confirm the same. Assays capable of estimating neutralizing and enhancing potential of immune serum, such as those involving use of complement and complement receptor carrying target cells for C-ADE, have been proposed for a better understanding of the clinical relevance of vaccine-related ADE. Such assays would also provide stronger immune correlates during preclinical and clinical studies. Further, design of vaccine immunogens that will elicit protective and not enhancing antibodies, by avoiding inclusion of known enhancing epitopes, has been put forth as a mitigation strategy for HIV-ADE (Beck et al. 2008).

\subsection{Influenza Virus}

Influenza is a highly communicable acute respiratory disease caused by infection with influenza virus of family Orthomyxoviridae. The disease is a serious health threat of epidemic and pandemic proportions, with severe cases associated with pneumonia and lung tissue damage. Influenza A viruses are the most common in human infections and are further classified into subtypes on the basis of the two surface proteins, hemagglutinin $(\mathrm{H})$ and neuraminidase $(\mathrm{N})$, with $18 \mathrm{H}$ and $11 \mathrm{~N}$ subtypes identified (Shao et al. 2017). Influenza A virus undergoes rapid evolution due to mechanisms such as antigenic drift, shift, and genetic reassortment, resulting in periodic emergence of novel viral strains. Annual vaccination against the circulating viral strain is thus implemented for protection against the disease.

Epithelial cells of the respiratory tract are the primary targets of influenza virus infection; however, in vitro ADE of this virus has been reported in primary macrophages and macrophage-like cell lines (P388D1), under the presence of monoclonal antibodies, mice, rabbit, or human immune sera (Ochiai et al. 1988, 1990, 1992; Tamura et al. 1991, 1994; Gotoff et al. 1994). Engagement of FcyRs by antibodies specific to viral HA and NA has been shown to mediate virus uptake, with subtype cross-reactive non-neutralizing antibodies being particularly involved in infection enhancement of heterotypic viruses (different HA/NA type). While such internalization usually results in abortive infection of macrophages, productive replication in 
these cells has been shown to be possible in the presence of appropriate protease for HA cleavage. Increased presentation of viral antigens by the infected macrophages leading to augmented virus-specific T-cell activation is also suggested to contribute to viral pathogenesis. Enhancement of virus fusion by anti-HA2 subunit antibodies is another mechanism of influenza-ADE and has been shown to be responsible for the occurrence of vaccine-associated enhanced respiratory disease (VAERD) in pigs immunized with inactivated H1N2 vaccine and challenged with pandemic 2009 H1N1 virus (Gauger et al. 2011; Khurana et al. 2013). Influenza-ADE is also suggested by epidemiologic observations in humans. Retrospective analysis of medical records from the 1918 influenza pandemic revealed association of prior influenzalike illness with increased risk of medically attended illness during the pandemic period (Shanks et al. 2016). More recently, prior receipt of seasonal influenza vaccine was found to increase the risk of medically attended pandemic H1N1 illness during 2009 in Canada (Skowronski et al. 2010). Furthermore, presence of high titer non-protective serum antibodies was associated with immune complex-mediated severe H1N1 illness during this pandemic (Monsalvo et al. 2011; To et al. 2012).

Observation of VAERD in pigs and ferrets immunized with inactivated or HA subunit vaccines raises concern regarding the safety of vaccines, particularly universal influenza vaccines (Gauger et al. 2011; Khurana et al. 2013; Rajao et al. 2014; Skowronski et al. 2014). However, vaccine-mediated protection and absence of VAERD is also reported in few studies in pigs, suggesting that vaccine-induced ADE occurs only in certain conditions, which are not yet clearly understood (Reeth et al. 2004; Kyriakis et al. 2010; Ricklin et al. 2016). Regarding therapeutic candidates, Phase 2 studies of anti-HA stalk mAbs have indicated possibility of enhanced viral shedding in some treated human subjects. Screening for high potency protective antibodies, defining optimal dose range for effective neutralization, using cocktails of mAbs with different antigen specificities, has been suggested for mitigation of ADE (Chan-Hui and Swiderek 2016).

\subsection{Respiratory Syncytial Virus}

Respiratory syncytial virus (RSV), a member of family Paramyxoviridae, genus Pneumovirus, is the leading cause of lower respiratory tract infections among infants and young children worldwide, with severe disease requiring hospitalization occurring most frequently between 6 weeks and 6 months of life (Glezen et al. 1986; Hall et al. 2009). RSV disease is also a major health problem in adults and the elderly. Severe bronchiolitis is one of the major outcomes of RSV infection.

Observation of enhanced disease among children receiving the formalininactivated RSV (FI-RSV) vaccine in the 1960s (Kim et al. 1969), as well as the frequent occurrence of severe disease among infants $<6$ months of age, when maternal antibodies are present, prompted investigations on ADE of RSV infections. Subsequently, enhancement of RSV infection by RSV-specific monoclonal antibodies and human immune sera was demonstrated in vitro in monocytic (U937, THP-1) and macrophage-like (P388D1) cell lines (Gimenez et al. 1989, 1996; Krilov et al. 
1989; Osiowy et al. 1994). The phenomenon has also been reported in Bonnet monkeys developing enhanced disease following FI-RSV immunization (Ponnuraj et al. 2001, 2003). Fc $\gamma$ R-mediated internalization of immune complexes is the suggested mechanism, with antibodies against the viral surface glycoproteins, the attachment glycoprotein $(\mathrm{G})$ and fusion glycoprotein $(\mathrm{F})$, playing an important role. Although epithelial cells of the respiratory tract are primary targets of RSV infection, it has been suggested that alveolar macrophages are infected through ADE, resulting in activation of Th2 response and increased expression of TNF- $\alpha$, IL- 6 , thus causing enhanced disease (Gimenez et al., 1996). Further, ADE-mediated infection of lung dendritic cells (DCs) has been demonstrated to negatively modulate DC cell function, resulting in impaired T-cell activation, and has been suggested to contribute to RSV pathogenesis (Gomez et al. 2016). However, the clinical effects of RSV-ADE still remain unclear with different studies reporting contradictory observations regarding the association of maternal antibody-induced ADE and disease severity in infants (Chanock et al. 1970; van Erp et al. 2017).

Enhanced RSV disease in FI-RSV vaccine recipients was initially attributed to vaccine-induced ADE; however, recent studies have suggested a role of other mechanisms involving T cells (Huisman et al. 2009). Whether ADE would affect the efficacy of other RSV vaccines in development remains to be seen. As far as immunotherapeutics are concerned, the F protein-specific humanized monoclonal antibody, Palivizumab, is the only clinically approved intervention. This mAb has demonstrated ADE at sub-neutralizing concentrations in vitro, yet has been found to have a protective effect in animal models and humans (TI-RS Group 1998; Mej1as et al. 2004; van Mechelen et al. 2016).

\subsection{Ebola Virus}

Ebola virus is a member of family Filoviridae. Of the four Ebola virus species infecting humans, Zaire ebolavirus (EBOV) is the most virulent and is the causative agent of a severe hemorrhagic fever disease, Ebola virus disease (EVD), with a fatality rate of $\sim 90 \%$ (Feldmann and Geisbert 2011). The disease is zoonotic, with initial cases occurring due to contact with infected fruit bats (reservoir) or their contaminated material, followed by human-to-human transmission. The virus is mainly endemic in Africa; however, due to its increased incidence and fast spread, as observed during the 2014-2016 African outbreak, the virus is considered a pandemic threat.

$\mathrm{ADE}$ of Ebola virus infection has been demonstrated in vitro in a variety of cell lines and is shown to be mediated by antibodies specific to the viral envelope glycoprotein (GP) (Takada et al. 2001, 2003, 2007). Such enhancing antibodies have been identified in the sera of EVD patients (Takada et al. 2003; Furuyama et al. 2016). Two different mechanisms have been proposed for ADE of EBOV infection: (a) Fc $\gamma$ R-mediated ADE and (b) C1q-mediated ADE. In FcyR-mediated ADE, antibody-virus complexes bind cell surface Fc $\gamma$ RIIA triggering phosphorylation of Src family protein tyrosine kinases (PTKs) and activation of Src signaling pathways 
leading to virus uptake through phagocytosis and/or micropinocytosis (Furuyama et al. 2016). C1q-mediated ADE involves interaction of virus-bound antibodies with complement component $\mathrm{C} 1 \mathrm{q}$ and subsequent attachment to cell surface $\mathrm{C} 1 \mathrm{q}$ receptors, leading to virus internalization by $\mathrm{C} 1 \mathrm{q}$ receptor-mediated endocytosis or via virus-specific receptor (Takada et al. 2003, 2007). C1q receptors are present on monocytes/macrophages, which are primary targets of EBOV, as well as most other mammalian cells, including endothelial cells, epithelial cells, and hepatocytes. C1qADE mediated dissemination of EBOV infection to these "secondary target cells" has been suggested to exacerbate disease.

Although clinical relevance of EBOV-ADE is not yet understood, repeated in vitro demonstrations raise concerns regarding safety of vaccines and immunotherapeutics. Several candidate vaccines under development have demonstrated protective efficacy in preclinical studies and immunogenicity in clinical trials (Dhama et al. 2018). The protective effect of these vaccines seems to depend on cytotoxic T-cell responses. Avoiding induction of known infectivity-enhancing antibodies while retaining T-cell epitopes should thus be considered during vaccine design. For immunotherapy, the use of well-characterized mAbs instead of polyclonal convalescent human serum has been suggested to reduce ADE.

\subsection{Severe Acute Respiratory Syndrome: Coronavirus}

Severe acute respiratory syndrome (SARS) is a respiratory disease caused by SARS-coronavirus (SARS-CoV) of family Coronaviridae, which caused outbreaks mainly in China, during 2002-2003. Although public health measures successfully contained further spread and human outbreaks, future reemergence of SARS-CoV or other related viruses remains a credible threat due to the zoonotic origin of this virus.

ADE of SARS-CoV infection was first demonstrated in vitro in human B cells using sera from immunized animals as well as convalescent patients (Kam et al. 2007). Further studies showed that antibodies specific to the viral surface spike glycoprotein $(S)$ are capable of enhancing viral infection of immune cells, particularly monocytes and macrophages, thus allowing the virus to broaden its cellular tropism (Jaume et al. 2011; Wang et al. 2014; Yip et al. 2014). Internalization of the immune complexes by cellular Fc $\gamma$ Rs, mainly Fc $\gamma$ RIIA, is the suggested mechanism, with intracellular signaling by the Fc $\gamma \mathrm{R}$ cytosolic domain playing an important role. This FcyR-mediated internalization follows a $\mathrm{pH}-$ and cysteine protease-independent pathway and differs from the endosomal/lysosomal pathway utilized by angiotensin I-converting enzyme 2 (ACE2), the accepted receptor for SARS-CoV. Such antibody-mediated infection of macrophages, however, was not found to support productive virus replication or modify expression of cytokines/ chemokines (Yip et al. 2016). Although demonstrated recently in rhesus monkeys (Wang et al. 2016), the occurrence of SARS-ADE and its association with disease severity in humans are still debated, with different clinical studies reporting both 
protective and disease-enhancing effects of anti-SARS-CoV antibodies (Lee et al. 2006; Zhang et al. 2006).

\subsection{Chikungunya Virus}

Chikungunya virus (CHIKV) is an arbovirus belonging to family Togaviridae, genus Alphavirus. The virus is recognized as a significant global health threat since the last decade. It is primarily transmitted through the bite of infected Aedes mosquitoes, Aedes aegypti and Aedes albopictus. CHIKV infection is associated with a febrile illness accompanied by myalgia, arthralgia, and cutaneous rash (Kam et al. 2009). Debilitating persistent polyarthralgia is the characteristic feature of Chikungunya disease.

ADE of CHIKV infection was suggested by the association of low titers of antiCHIKV IgG in immunized mice with the early onset of disease upon subsequent CHIKV challenge (Hallengard et al. 2014). Another recent study observed enhanced attachment of CHIKV to primary human monocytes and B cells and increased viral replication in the murine macrophage cell line, RAW264.7, in the presence of antiCHIKV antibodies (Lum et al. 2018). Further, this study also detected higher viral RNA load and enhancement of disease severity in mice infected with CHIKV in the presence of sub-neutralizing concentrations of antibody, thus providing the first evidence for ADE of CHIKV infection and disease. The enhancement was found to be Fc $\gamma$ R-mediated, with Fc $\gamma$ RII playing a predominant role. However, ADE of CHIKV infection has not been reported to date in humans, and thus, the clinical significance of these findings remains unknown and warrants further investigation.

\subsection{Concluding Remarks}

Virus-specific antibodies function to neutralize virus infection and are an important component of the host antiviral immune response. However, under sub-neutralizing or non-neutralizing conditions, the antibodies are capable of enhancing viral infection by providing an alternative route of virus entry into host cells. This phenomenon of antibody-dependent enhancement facilitates viral infection of a larger number of primary target cells and also allows viral entry into otherwise nonsusceptible secondary target cells, thus broadening the virus tropism. Moreover, ADE also modulates the host intracellular signaling pathways, thereby turning down the antiviral immune response. Together these mechanisms serve to augment viral replication and pathogenesis, with the balance between neutralizing and enhancing antibodies influencing the outcome of viral infection and disease.

ADE has been demonstrated in vitro and in animal models for a number of viruses including DENV, HIV, influenza, RSV, Ebola, SARS-CoV, and CHIKV. While the occurrence of DENV-ADE in humans and its association with severe disease have been clearly demonstrated, the clinical relevance of ADE in other viruses is not completely understood. Nevertheless, ADE remains a concern in 
development and use of vaccines and immunotherapeutics against these viruses. Recent advances in identification of neutralizing and enhancing viral epitopes are expected to guide future design of non-enhancing, protective viral vaccines and therapeutic mAbs. Comprehensive evaluation of humoral and cell-mediated immune response to vaccines in preclinical and clinical studies, with the help of robust assays that can detect ADE, is suggested to be crucial for the assessment of vaccine safety and efficacy. Such evaluations would require a better understanding of the immune correlates of protection. Lastly, investigation of long-term effects of vaccine implementation is advisable while considering approval for future vaccines.

Acknowledgments The author is grateful to Dr. A.C. Mishra, Director, IRSHA, and Dr. V.A. Arankalle, Head, Department of Communicable Diseases, IRSHA, for their constant support.

Conflict of Interest The authors declare that they have no competing interests.

\section{References}

Acosta EG, Bartenschlager R (2016) Paradoxical role of antibodies in dengue virus infections: considerations for prophylactic vaccine development. Expert Rev Vaccines 15(4):467-482

Alvarez M, Rodriguez-Roche R, Bernardo L, Vazquez S, Morier L, Gonzalez D, Castro O, Kouri G, Halstead SB, Guzman MG (2006) Dengue hemorrhagic fever caused by sequential dengue 1-3 virus infections over a long time interval: Havana epidemic, 2001-2002. Am J Trop Med Hyg 75:1113-1117

Appanna R, Wang SM, Ponnampalavanar SA, Lum LC, Sekaran SD (2012) Cytokine factors present in dengue patient sera induces alterations of junctional proteins in human endothelial cells. Am J Trop Med Hyg 87:936-942

Ayala-Nunez NV, Hoornweg TE, van de Pol DP, Sjollema KA, Flipse J, van der Schaar HM, Smit JM (2016) How antibodies alter the cell entry pathway of dengue virus particles in macrophages. Sci Rep 6:28768

Balsitis SJ, Williams KL, Lachica R, Flores D, Kyle JL, Mehlhop E, Johnson S, Diamond MS, Beatty PB, Harris E (2010) Lethal antibody enhancement of dengue disease in mice is prevented by Fc modification. PLoS Pathog 6(2):e1000790

Banhegyi D, Bacsi A, Toth FD, Prohaszka Z, Horvath A, Beck Z, Konya J, Fust G (2003) Significant decrease of the enhancement/neutralization index in HIV patients during highly active antiretroviral therapy (HAART). Immunol Lett 89(1):25-30

Bardina SV, Bunduc P, Tripathi S, Duehr J, Frere JJ, Brown JA, Nachbagauer R, Foster GA, Krysztof D, Tortorella D et al (2017) Enhancement of Zika virus pathogenesis by preexisting antiflavivirus immunity. Science 356(6334): 175-180

Beck Z, Prohászka Z, Füst G (2008) Traitors of the immune system-enhancing antibodies in HIV infection: their possible implication in HIV vaccine development. Vaccine 26(24):3078-3085

Beltramello M, Williams KL, Simmons CP, Macagno A, Simonelli L, Quyen NT, Sukupolvi-Petty S, Navarro-Sanchez E, Young PR, de Silva AM et al (2010) The human immune response to dengue virus is dominated by highly cross-reactive antibodies endowed with neutralizing and enhancing activity. Cell Host Microbe 8(3):271-283

Bhatt S, Gething PW, Brady OJ, Messina JP, Farlow AW, Moyes CL, Drake JM, Brownstein JS, Hoen AG, Sankoh O (2013) The global distribution and burden of dengue. Nature 496(7446):504-507 
Boonnak K, Slike BM, Donofrio GC, Marovich MA (2013) Human Fc $\gamma$ RII cytoplasmic domains differentially influence antibody-mediated dengue virus infection. J Immunol 190(11):5659-5665

Braciale TJ, Hahn YS, Burton DR (2013) Adaptive immune response to viral infections. In: Knipe DM, Howley PM (eds) Fields Virology, 6th edn. Lippincott Williams and Wilkins, Philadelphia, pp 214-253

Capeding MR, Tran NH, Hadinegoro SR, Ismail HI, Chotpitayasunondh T, Chua MN, Luong CQ, Rusmil K, Wirawan DN, Nallusamy R et al (2014) Clinical efficacy and safety of a novel tetravalent dengue vaccine in healthy children in Asia: a phase 3, randomised, observer-masked, placebo-controlled trial. Lancet 384:1358-1365

Cardosa MJ (1987) Dengue virus isolation by antibody-dependent enhancement of infectivity in macrophages. Lancet 329(8526):193-194

Cardosa MJ, Porterfield JS, Gordon S (1983) Complement receptor mediates enhanced flavivirus replication in macrophages. J Exp Med 158:258-263

Carro AC, Piccini LE, Damonte EB (2018) Blockade of dengue virus entry into myeloid cells by endocytic inhibitors in the presence or absence of antibodies. PLoS Negl Trop Dis 12(8): 0006685

Castilla V, Piccini LE, Damonte EB (2015) Dengue virus entry and trafficking: perspectives as antiviral target for prevention and therapy. Future Virol 10:625-645

Chan KR, Ong EZ, Ooi EE (2013) Therapeutic antibodies as a treatment option for dengue fever. Expert Rev Anti-Infect Ther 11(11):1147-1157

Chan KR, Ong EZ, Tan HC, Zhang SL, Zhang Q, Tang KF, Kaliaperumal N, Lim AP, Hibberd ML, Chan SH et al (2014) Leukocyte immunoglobulin-like receptor B1 is critical for antibodydependent dengue. Proc Natl Acad Sci U S A 111(7):2722-2727

Chan KR, Wang X, Saron WAA, Gan ES, Tan HC, Mok DZ, Zhang SL, Lee YH, Liang C, Wijaya $\mathrm{L}$ et al (2016) Cross-reactive antibodies enhance live attenuated virus infection for increased immunogenicity. Nat Microbiol 1:16164

Chan-Hui PY, Swiderek KM (2016) Immunological considerations for developing antibody therapeutics for Influenza A. Hum Vaccin Immunother 12(2):474-477

Chanock RM, Kapikian AZ, Mills J, Kim HW, Parrott RH (1970) Influence of immunological factors in respiratory syncytial virus disease. Arch Environ Health 21(3):347-355

Chareonsirisuthigul T, Kalayanarooj S, Ubol S (2007) Dengue virus (DENV) antibody-dependent enhancement of infection upregulates the production of anti-inflammatory cytokines, but suppresses anti-DENV free radical and pro-inflammatory cytokine production, in THP-1 cells. J Gen Virol 88:365-375

Chaturvedi UC, Agarwal R, Elbishbishi EA, Mustafa AS (2000) Cytokine cascade in dengue hemorrhagic fever: implications for pathogenesis. FEMS Immunol Med Microbiol 28:183-188

Chau TN, Quyen NT, Thuy TT, Tuan NM, Hoang DM, Dung NT, Lien le B, Quy NT, Hieu NT, Hieu LT et al (2008) Dengue in Vietnamese infants-results of infection enhancement assays correlate with age-related disease epidemiology, and cellular immune responses correlate with disease severity. J Infect Dis 198:516-524

Chau TN, Hieu NT, Anders KL, Wolbers M, Lien le B, Hieu LT, Hien TT, Hung NT, Farrar J, Whitehead S et al (2009) Dengue virus infections and maternal antibody decay in a prospective birth cohort study of Vietnamese infants. J Infect Dis 200:1893-1900

Chawla T, Chan KR, Zhang SL, Tan HC, Lim APC, Hanson BJ, Ooi EE (2013) Dengue virus neutralization in cells expressing fc gamma receptors. PLoS One 8(5):e65231

Chotiwan N, Roehrig JT, Schlesinger JJ, Blair CD (2014) Molecular determinants of dengue virus 2 envelope protein important for virus entry in Fc $\gamma$ RIIA-mediated antibody-dependent enhancement of infection. Virology 456-457:238-246

Connor RI, Dinces NB, Howell AL, Romet-Lemonne J-L, Pasquali J-L, Fanger MW (1991) Fc receptors for $\mathrm{IgG}(\mathrm{Fc} \gamma \mathrm{Rs})$ on human monocytes and macrophages are not infectivity receptors for human immunodeficiency virus type 1 (HIV-1): studies using bispecific antibodies to target HIV-1 to various myeloid cell surface molecules, including the FcyR. Proc Natl Acad Sci U S A 88:9593-9597 
Crill WD, Chang G-JJ (2004) Localization and characterization of flavivirus envelope glycoprotein cross-reactive epitopes. J Virol 78(24):13975-13986

Crill WD, Hughes HR, Trainor NB, Davis BS, Whitnet MT, Chang G-JJ (2012) Sculpting humoral immunity through dengue vaccination to enhance protective immunity. Front Immunol 3:334

Cruz-Oliveira C, Freire JM, Conceicão TM, Higa LM, Castanho MA, Da Poian AT (2015) Receptors and routes of dengue virus entry into the host cells. FEMS Microbiol Rev 39:155-170

Davis D, Trischmann H, Stephens DM, Lachmann PJ (2001) Antibodies raised to short synthetic peptides with sequences derived from HIV-1 SF2 gp120 can both neutralize and enhance HIV-1 SF13: a later variant isolated from the same host. J Med Virol 64(3):207-216

Dejnirattisai W, Jumnainsong A, Onsirisakul N, Fitton P, Vasanawathana S, Limpitikul W, Puttikhunt C, Edwards C, Duangchinda T, Supasa S et al (2010) Cross-reacting antibodies enhance dengue virus infection in humans. Science 328:745-748

Dejnirattisai W, Wongwiwat W, Supasa S, Zhang X, Dai X, Rouvinski A, Jumnainsong A, Edwards C, Quyen NTH, Duangchinda T et al (2015) A new class of highly potent, broadly neutralizing antibodies isolated from viremic patients infected with dengue virus. Nat Immunol 16:170-177

Dewi BE, Takasaki T, Kurane I (2004) In vitro assessment of human endothelial cell permeability: effects of inflammatory cytokines and dengue virus infection. J Virol Methods 121:171-180

Dhama K, Karthik K, Khandia R, Chakraborty S, Munjal A, Latheef SK, Kumar D, Ramakrishnan MA, Malik YS, Singh R et al (2018) Advances in designing and developing vaccines, drugs, and therapies to counter Ebola virus. Front Immunol 9:1803

Dowd KA, Jost CA, Durbin AP, Whitehead SS, Pierson TC (2011) A dynamic landscape for antibody binding modulates antibody-mediated neutralization of West Nile virus. PLoS Pathog 7:e1002111

Feldmann H, Geisbert TW (2011) Ebola haemorrhagic fever. Lancet 377(9768):849-862

Fibriansah G, Tan JL, Smith SA, de Alwis R, Ng TS, Kostyuchenko VA, Jadi RS, Kukkaro P, de Silva AM, Crowe JE et al (2015) A highly potent human antibody neutralizes dengue virus serotype 3 by binding across three surface proteins. Nat Commun 6:6341

Flipse J, Diosa-Toro MA, Hoornweg TE, van de Pol DP, Urcuqui-Inchima S, Smit JM (2016) Antibody-dependent enhancement of dengue virus infection in primary human macrophages; balancing higher fusion against antiviral responses. Sci Rep 6:29201

Frei JC, Wirchnianski AS, Govero J, Vergnolle O, Dowd KA, Pierson TC, Kielian M, Girvin ME, Diamond MS, Lai JR (2018) Engineered dengue virus domain III proteins elicit crossneutralizing antibody responses in mice. J Virol 92(18):e01023-e01018

Furuyama W, Marzi A, Carmody AB, Maruyama J, Kuroda M, Miyamoto H, Nanbo A, Manzoor $\mathrm{R}$, Yoshida R, Igarashi M et al (2016) Fc $\gamma$-receptor IIa-mediated Src signaling pathway is essential for the antibody-dependent enhancement of Ebola virus infection. PLoS Pathog 12(12):e1006139

Fust G, Toth FD, Kiss J, Ujhelyi E, Nagy I, Banhegyi D (1994) Neutralizing and enhancing antibodies measured in complement-restored serum samples from HIV-1-infected individuals correlate with immunosuppression and disease. AIDS 8(5):603-609

Gan ES, Ting DH, Chan KR (2017) The mechanistic role of antibodies to dengue virus in protection and disease pathogenesis. Expert Rev Anti-Infect Ther 15(2):111-119

Gauger PC, Vincent AL, Loving CL, Lager KM, Janke BH, Kehrli ME Jr, Roth JA (2011) Enhanced pneumonia and disease in pigs vaccinated with an inactivated human-like (delta-cluster) H1N2 vaccine and challenged with pandemic 2009 H1N1 influenza virus. Vaccine 29(15):2712-2719

George J, Valiant WG, Mattapallil MJ, Walker M, Huang Y-JS, Vanlandingham DL, Misamore J, Greenhouse J, Weiss DE, Verthelyi D et al (2017) Prior exposure to Zika virus significantly enhances peak dengue-2 viremia in rhesus macaques. Sci Rep 7:10498

Ghosn J, Taiwo B, Seedat S, Autran B, Katlama C (2018) HIV. Lancet 392(10148):685-697

Gibbons RV, Kalanarooj S, Jarman RG, Nisalak A, Vaughn DW, Endy TP, Mammen MP Jr, Srikiatkhachorn A (2007) Analysis of repeat hospital admissions for dengue to estimate the frequency of third or fourth dengue infections resulting in admissions and dengue hemorrhagic fever, and serotype sequences. Am J Trop Med Hyg 77:910-913 
Gil L, Izquierdo A, Lazo L, Valdes I, Ambala P, Ochola L, Marcos E, Suzarte E, Kariuki T, Guzmán $\mathrm{G}$ et al (2014) Capsid protein: evidences about the partial protective role of neutralizing antibody independent immunity against dengue in monkeys. Virology 456-457:70-76

Gil L, Lazo L, Valdés I, Suzarte E, Yen P, Ramírez R, Álvarez M, Dung LT, Cobas K, Marcos E et al (2017) The tetravalent formulation of domain III-capsid proteins recalls memory B-and T-cell responses induced in monkeys by an experimental dengue virus infection. Clin Transl Immunology 6(6):e148

Gilbert PB, Peterson ML, Follmann D, Hudgens MG, Francis DP, Gurwith M, Heyward WL, Jobes DV, Popovic V, Self SG et al (2005) Correlation between immunologic responses to a recombinant glycoprotein 120 vaccine and incidence of HIV-1 infection in a phase 3 HIV-1 preventive vaccine trial. J Infect Dis 191:666-677

Gimenez HB, Keir HM, Cash P (1989) In vitro enhancement of respiratory syncytial virus infection of U937 cells by human sera. J GenVirol 70:89-96

Gimenez HB, Chisholm S, Dornan J, Cash P (1996) Neutralizing and enhancing activities of human respiratory syncytial virus-specific antibodies. Clin Diagn Lab Immunol 3:280-286

Glezen WP, Taber LH, Frank AL, Kasel JA (1986) Risk of primary infection and reinfection with respiratory syncytial virus. Am J Dis Child 140:543-546

Gomez RS, Ramirez BA, Cespedes PF, Cautivo KM, Riquelme SA, Prado CE, Gonzalez PA, Kalergis AM (2016) Contribution of Fcgamma receptors to human respiratory syncytial virus pathogenesis and the impairment of T-cell activation by dendritic cells. Immunology 147:55-72

Goncalvez AP, Engle RE, St Claire M, Purcell RH, Lai CJ (2007) Monoclonal antibody-mediated enhancement of dengue virus infection in vitro and in vivo and strategies for prevention. Proc Natl Acad Sci U S A 104:9422-9427

Gotoff R, Tamura M, Janus J, Thompson J, Wright P, Ennis FA (1994) Primary influenza A virus infection induces cross-reactive antibodies that enhance uptake of virus into Fc receptor/bearing cells. J Infect Dis 169:200-203

Gould EA, Buckley A (1989) Antibody-dependent enhancement of yellow fever and Japanese encephalitis virus neurovirulence. J Gen Virol 70(Pt 6):1605-1608

Graham RR, Juffrie M, Tan R, Hayes CG, Laksono I, Ma'roef C, Erlin, Sutaryo, Porter KR, Halstead SB (1999) A prospective seroepidemiologic study on dengue in children four to nine years of age in Yogyakarta, Indonesia I. studies in 1995-1996. Am J Trop Med Hyg 61:412-419

Guilliams M, Bruhns P, Saeys Y, Hammad H, Lambrecht BN (2014) The function of Fcy receptors in dendritic cells and macrophages. Nat Rev Immunol 14:94-108

Guillon C, Schutten M, Boers PH, Gruters RA, Osterhaus AD (2002) Antibody-mediated enhancement of human immunodeficiency virus type 1 infectivity is determined by the structure of gp120 and depends on modulation of the gp120-CCR5 interaction. J Virol 76:2827-2834

Guzman MG, Kouri GP, Bravo J, Soler M, Vazquez S, Morier L (1990) Dengue hemorrhagic fever in Cuba, 1981: a retrospective seroepidemiologic study. Am J Trop Med Hyg 42:179-184

Guzman MG, Kouri G, Valdes L, Bravo J, Alvarez M, Vazquez S, Delgado I, Halstead SB (2000) Epidemiologic studies on dengue in Santiago de Cuba, 1997. Am J Epidemiol 152:793-799

Guzman MG, Alvarez M, Halstead SB (2013) Secondary infection as a risk factor for dengue hemorrhagic fever/dengue shock syndrome: an historical perspective and role of antibodydependent enhancement of infection. Arch Virol 158(7):1445-1459

Hadinegoro SR, Arredondo-Garcia JL, Capeding MR, Deseda C, Chotpitayasunondh T, Dietze R, Muhammad Ismail HI, Reynales H, Limkittikul K, Rivera-Medina DM et al (2015) Efficacy and long-term safety of dengue vaccine in regions of endemic disease. N Engl J Med 373:1195-1206

Hall CB, Weinberg GA, Iwane MK, Blumkin AK, Edwards KM, Staat MA, Auinger P, Griffin MR, Poehling KA, Erdman D, Grijalva CG, Zhu Y, Szilagyi P (2009) The burden of respiratory syncytial virus infection in young children. N Engl J Med 360:588-598

Hallengard D, Lum FM, Kümmerer BM, Lulla A, Lulla V, García-Arriaza J, Fazakerley JK, Roques P, Le Grand R, Merits A et al (2014) Prime-boost immunization strategies against Chikungunya virus. J Virol 88(22):13333-13343 
Halstead SB (1979) In vivo enhancement of dengue virus infection in rhesus monkeys by passively transferred antibody. J Infect Dis 140:527-533

Halstead SB (2003) Neutralization and antibody-dependent enhancement of dengue viruses. Adv Virus Res 60:421-467

Halstead SB (2008) Pathogenesis: risk factors prior to infection. In: Halstead SB (ed) Dengue. Imperial College Press, London, pp 219-256

Halstead SB, Nimmannitya S, Yamarat C, Russell PK (1967) Hemorrhagic fever in Thailand: recent knowledge regarding etiology. Jpn J Med Sci Biol 20:96-103

Halstead SB, Chow J, Marchette NJ (1973a) Immunologic enhancement of dengue virus replication. Nat New Biol 243:24-26

Halstead SB, Shotwell H, Casals J (1973b) Studies on the pathogenesis of dengue infection in monkeys. II. Clinical laboratory responses to heterologous infection. J Infect Dis 128:15-22

Hawkes RA (1964) Enhancement of the infectivity of arboviruses by specific antisera produced in domestic fowls. Aust J Exp Biol Med Sci 42:465-482

Hawkes RA, Lafferty KJ (1967) The enhancement of virus infectivity by antibody. Virology 33:250-261

Hertz T, Beatty PR, MacMillen Z, Killingbeck SS, Wang C, Harris E (2017) Antibody epitopes identified in critical regions of dengue virus nonstructural 1 protein in mouse vaccination and natural human infections. J Immunol 198(10):4025-4035

Homsy J, Meyer M, Tateno M, Clarkson S, Levy JA (1989) The Fc and not CD4 receptor mediates antibody enhancement of HIV infection in human cells. Science 244(4910):1357-1360

Homsy J, Meyer M, Levy JA (1990) Serum enhancement of human immunodeficiency virus (HIV) infection correlates with disease in HIV-infected individuals. J Virol 64:1437-1440

Huisman W, Martina BEE, Rimmelzwaan GF, Gruters RA, Osterhaus ADME (2009) Vaccineinduced enhancement of viral infections. Vaccine 27:505-512

Injampa S, Muenngern N, Pipattanaboon C, Benjathummarak S, Boonha K, Hananantachai $\mathrm{H}$, Wongwit W, Ramasoota P, Pitaksajjakul P (2017) Generation and characterization of cross neutralizing human monoclonal antibody against 4 serotypes of dengue virus without enhancing activity. Peer J 5:e4021

Janoff EN, Wahl SM, Thomas K, Smith PD (1995) Modulation of human immunodeficiency virus type 1 infection of human monocytes by IgA. J Infect Dis 172:855-858

Jaume M, Yip MS, Cheung CY, Leung HL, Li PH, Kien F, Dutry I, Callendret B, Escriou N, Altmeyer R et al (2011) Anti-severe acute respiratory syndrome coronavirus spike antibodies trigger infection of human immune cells via a $\mathrm{pH}$ - and cysteine protease-independent Fc $\gamma \mathrm{R}$ pathway. J Virol 85:10582-10597

Junjhon J, Edwards TJ, Utaipat U, Bowman VD, Holdaway HA, Zhang W, Keelapang P, Puttikhunt C, Perera R, Chipman PR et al (2010) Influence of pr-M cleavage on the heterogeneity of extracellular dengue virus particles. J Virol 84(16):8353-8358

Kam YW, Kien F, Roberts A, Cheung YC, Lamirande EW, Vogel L, Chu SL, Tse J, Guarner J, Zaki SR et al (2007) Antibodies against trimeric S glycoprotein protect hamsters against SARS-CoV challenge despite their capacity to mediate FcgammaRII-dependent entry into B cells in vitro. Vaccine 25:729-740

Kam YW, Ong EK, Rénia L, Tong JC, Ng LF (2009) Immuno-biology of chikungunya and implications for disease intervention. Microbes Infect 11(14-15):1186-1196

Katzelnick LC, Harris E (2017) Immune correlates of protection for dengue: state of the art and research agenda. Vaccine 35:4659-4669

Katzelnick LC, Gresh L, Halloran ME, Mercado JC, Kuan G, Gordon A, Balmaseda A, Harris E (2017) Antibody-dependent enhancement of severe dengue disease in humans. Science 358(6365):929-932

Khurana S, Loving CL, Manischewitz J, King LR, Gauger PC, Henningson J, Vincent AL, Golding H (2013) Vaccine-induced anti-HA2 antibodies promote virus fusion and enhance influenza virus respiratory disease. Sci Transl Med 5(200):200ra114 
Kim HW, Canchola JG, Brandt CD, Pyles G, Chanock RM, Jensen K, Parrott RH (1969) Respiratory syncytial virus disease in infants despite prior administration of antigenic inactivated vaccine. Am J Epidemiol 89:422-434

Klasse PJ, Sattentau QJ (2002) Occupancy and mechanism in antibody-mediated neutralization of animal viruses. J Gen Virol 83:2091-2108

Kliks S (1990) Antibody-enhanced infection of monocytes as the pathogenetic mechanism for severe dengue illness. AIDS Res Hum Retrovir 6(8):993-998

Kliks SC, Nimmanitya S, Nisalak A, Burke DS (1988) Evidence that maternal dengue antibodies are important in the development of dengue hemorrhagic fever in infants. Am J Trop Med Hyg 38:411-419

Kozlowski PA, Black KP, Shen L, Jackson S (1995) High prevalence of serum IgA HIV-1 infectionenhancing antibodies in HIV-infected persons. Masking by IgG. J Immunol 154:6163-6173

Krilov LR, Anderson LJ, Marcoux L, Bonagura VR, Wedgwood JF (1989) Antibody-mediated enhancement of respiratory syncytial virus infection in two monocyte/macrophage cell lines. J Infect Dis 160:777-782

Kyriakis CS, Gramer MR, Barbe F, Van Doorsselaere J, Van Reeth K (2010) Efficacy of commercial swine influenza vaccines against challenge with a recent European H1N1 field isolate. Vet Microbiol 144(1-2):67-74

Laurence J, Saunders A, Early E, Salmon JE (1990) Human immunodeficiency virus infection of monocytes: relationship to Fc-gamma receptors and antibody-dependent viral enhancement. Immunology 70:338-343

Lee N, Chan PK, Ip M, Wong E, Ho J, Ho C, Cockram CS, Hui DS (2006) Anti-SARS-CoV $\mathrm{IgG}$ response in relation to disease severity of severe acute respiratory syndrome. J Clin Virol 35:179-184

Li L, Lok SM, Yu I-M, Zhang Y, Kuhn RJ, Chen J, Rossmann MG (2008) The flavivirus precursor membrane-envelope protein complex: structure and maturation. Science 319(5871):1830-1834

Li M, Zhao L, Zhang C, Wang X, Hong W, Sun J, Liu R, Yu L, Wang J, Zhang F et al (2018) Dengue immune sera enhance Zika virus infection in human peripheral blood monocytes through Fc gamma receptors. PLoS One 13(7):e0200478

Lidbury BA, Mahalingam S (2000) Specific ablation of antiviral gene expression in macrophages by antibody-dependent enhancement of Ross River virus infection. J Virol 74:8376-8381

Lindenbach BD, Murray CL, Thiel H-J, Rice CM (2013) Flaviviridae. In: Knipe DM, Howley PM (eds) Fields virology, 6th edn. Lippincott Williams and Wilkins, Philadelphia, pp 712-746

Lu J, Wang R, Xia B, Yu Y, Zhou X, Yang Z, Huang P (2018) Potent neutralization ability of a human monoclonal antibody against serotype 1 dengue virus. Front Microbiol 9:1214

Lum FM, Couderc T, Chia BS, Ong RY, Her Z, Chow A, Leo YS, Kam YW, Rénia L, Lecuit M et al (2018) Antibody-mediated enhancement aggravates chikungunya virus infection and disease severity. Sci Rep 8(1):1860

Mahalingam S, Herring BL, Halstead SB (2013) Call to action for dengue vaccine failure. Emerg Infect Dis 19:1335-1337

Marchette NJ, Halstead SB, Falkler WA Jr, Stenhouse A, Nash D (1973) Studies on the pathogenesis of dengue infection in monkeys. III. Sequential distribution of virus in primary and heterologous infections. J Infect Dis 128:23-30

Matsui K, Gromowski GD, Li L, Barrett ADT (2010) Characterization of a dengue type-specific epitope on dengue 3 virus envelope protein domain III. J Gen Virol 91(Pt 9):2249-2253

McArthur MA, Sztein MB, Edelman R (2013) Dengue vaccines: recent developments, ongoing challenges and current candidates. Expert Rev Vaccines 12(8):933-953

Mejias A, Chavez-Bueno S, Rios AM, Saavedra-Lozano J, Fonseca Aten M, Hatfield J, Kapur P, Gómez AM, Jafri HS, Ramilo O (2004) Anti-respiratory syncytial virus (RSV) neutralizing antibody decreases lung inflammation, airway obstruction, and airway hyperresponsiveness in a murine RSV model. Antimicrob Agents Chemother 48:1811-1822

Meyer K, Ait-Goughoulte M, Keck Z-Y, Foung S, Ray R (2008) Antibody-dependent enhancement of hepatitis C virus infection. J Virol 82(5):2140-2149 
Modhiran N, Kalayanarooj S, Ubol S (2010) Subversion of innate defenses by the interplay between DENV and pre-existing enhancing antibodies: TLRs signaling collapse. PLoS Negl Trop Dis 4(12):e924

Modis Y, Ogata S, Clements D, Harrison SC (2004) Structure of the dengue virus envelope protein after membrane fusion. Nature 427:313-319

Moi ML, Takasaki T, Saijo M, Kurane I (2013) Dengue virus infection enhancing activity of undiluted sera obtained from patients with secondary dengue virus infection. Trans R Soc Trop Med Hyg 107(1):51-58

Monsalvo AC, Batalle JP, Lopez MF, Krause JC, Klemenc J, Hernandez JZ, Maskin B, Bugna J, Rubinstein C, Aguilar L et al (2011) Severe pandemic 2009 H1N1 influenza disease due to pathogenic immune complexes. Nat Med 17:195-199

Montefiori DC, Lefkowitz LB, Keller RE, Holmberg V, Sandtstrom E, Phair JP, Multicenter AIDS Cohort Study (1991) Absence of a clinical correlation for complement-mediated, infectionenhancing antibodies in plasma and sera from HIV-infected persons. AIDS 5:513-517

Morens DM, Larsen LK, Halstead SB (1987) Study of the distribution of antibody-dependent enhancement determinants on dengue 2 isolates using dengue 2-derived monoclonal antibodies. J Med Virol 22:163-167

Ng JK, Zhang SL, Tan HC, Yan B, Martinez JM, Tan WY, Lam JH, Tan GK, Ooi EE, Alonso S (2014) First experimental in vivo model of enhanced dengue disease severity through maternally acquired heterotypic dengue antibodies. PLoS Pathog 10:e1004031

Nguyen TH, Lei HY, Nguyen TL, Lin YS, Huang KJ, Le BL, Lin CF, Yeh TM, Do QH, Vu TQ (2004) Dengue hemorrhagic fever in infants: a study of clinical and cytokine profiles. J Infect Dis 189:221-232

Nimmerjahn F, Lux A (2014) LILR-B1 blocks activating Fc $\gamma$ R signaling to allow antibody dependent enhancement of dengue virus infection. Proc Natl Acad Sci U S A 111(7):2404-2405

Ochiai H, Kurokawa M, Hayashi K, Niwayama S (1988) Antibody mediated growth of influenza A NWS virus in macrophage-like cell line P388D1. J Virol 62:20-26

Ochiai H, Kurokawa M, Kuroki Y, Niwayama S (1990) Infection enhancement of influenza A H1 subtype viruses in macrophage-like P388D1 cells by cross-reactive antibodies. J Med Virol 30:258-265

Ochiai H, Kurokawa M, Matsui S, Yamamoto T, Kuroki Y, Kishimoto C, Shiraki K (1992) Infection enhancement of influenza A NWS virus in primary murine macrophages by anti-hemagglutinin monoclonal antibody. J Med Virol 36(3):217-221

Ong EZ, Zhang SL, Tan HC, Gan ES, Chan KR, Ooi EE (2017) Dengue virus compartmentalization during antibody-enhanced infection. Sci Rep 7:40923

Onyango-Makumbi C, Omer SB, Mubiru M, Moulton LH, Nakabiito C, Musoke P, Mmiro F, Zwerski S, Wigzell H, Falksveden L et al (2011) Safety and efficacy of HIV hyper immune globulin for prevention of mother-to-child HIV transmission in HIV-1-infected pregnant women and their infants in Kampala, Uganda (HIVIGLOB/NVP STUDY). J Acquir Immune Defic Syndr 58:399-407

Osiowy C, Horne D, Anderson R (1994) Antibody-dependent enhancement of respiratory syncytial virus infection by sera from young infants. Clin Diagn Lab Immunol 1:670-677

Pang T, Cardosa MJ, Guzman MG (2007) Of cascades and perfect storms: the immunopathogenesis of dengue haemorrhagic fever-dengue shock syndrome (DHF/DSS). Immunol Cell Biol 85(1):43-45

Ponnuraj EM, Hayward AR, Raj A, Wilson H, Simoes EAF (2001) Increased replication of respiratory syncytial virus (RSV) in pulmonary infiltrates is associated with enhanced histopathological disease in bonnet monkeys (Macaca radiata) pre-immunized with a formalin-inactivated RSV vaccine. J Gen Virol 82:2663-2674

Ponnuraj EM, Springer J, Hayward AR, Wilson H, Simoes EA (2003) Antibody dependent enhancement, a possible mechanism in augmented pulmonary disease of respiratory syncytial virus in the bonnet monkey model. J Infect Dis 187:1257-1263 
Prohaszka Z, Nemes J, Hidvegi T, Toth FD, Kerekes K, Erdei A, Szabó J, Ujhelyi E, Thielens N, Dierich MP et al (1997) Two parallel routes of the complement-mediated antibody-dependent enhancement of HIV-1 infection. AIDS 11(8):949-958

Puerta-Guardo H, Raya-Sandino A, González-Mariscal L, Rosales VH, Ayala-Dávila J, ChávezMungía B, Martínez-Fong D, Medina F, Ludert JE, del Angel RM (2013) The cytokine response of U937-derived macrophages infected through antibody-dependent enhancement of dengue virus disrupts cell apical-junction complexes and increases vascular permeability. $\mathbf{J}$ Virol 87(13):7486-7501

Rajao DS, Loving CL, Gauger PC, Kitikoon P, Vincent AL (2014) Influenza A virus hemagglutinin protein subunit vaccine elicits vaccine-associated enhanced respiratory disease in pigs. Vaccine 32(40):5170-5176

Reeth KV, Brown I, Essen S, Pensaert M (2004) Genetic relationships, serological cross-reaction and cross-protection between H1N2 and other influenza A virus subtypes endemic in European pigs. Virus Res 103(1-2):115-124

Ricklin ME, Vielle NJ, Python S, Brechbühl D, Zumkehr B, Posthaus H, Zimmer G, Summerfield A (2016) Partial protection against porcine influenza A virus by a hemagglutinin-expressing virus replicon particle vaccine in the absence of neutralizing antibodies. Front Immunol 7:253

Robinson WE Jr (2006) Mechanism for complement-mediated, antibody dependent enhancement of human immunodeficiency virus type 1 infection in MT2 cells is enhanced entry through CD4, CD21, and CXCR4 chemokine receptors. Viral Immunol 19(3):434-447

Robinson WE Jr, Montefiori DC, Mitchell WM (1987) A human immunodeficiency virus type 1 (HIV-1) infection-enhancing factor in seropositive sera. Biochem Biophys Res Commun 149(2):693-699

Robinson WE Jr, Montefiori DC, Mitchell WM (1988) Antibody dependent enhancement of human immunodeficiency virus type 1 infection. Lancet 1(8589):790-794

Robinson WE Jr, Montefiori DC, Gillespie DH, Mitchell WM (1989) Complement mediated, antibody-dependent enhancement of HIV-1 infection in vitro is characterized by increased protein and RNA syntheses and infectious virus release. J Acquir Immune Defic Syndr 2:33-42

Robinson WE Jr, Kawamura T, Lake D, Masuho Y, Mitchell WM, Hersh EM (1990a) Antibodies to the primary immunodominant domain of human immunodeficiency virus type 1 (HIV-1) glycoprotein gp4l enhance HIV-1 infection in vitro. J Virol 64(11):5301-5305

Robinson WE Jr, Kawamura T, Gorny MK, Lake D, Xu JY, Matsumoto Y, Sugano T, Masuho Y, Mitchell WM, Hersh E et al (1990b) Human monoclonal antibodies to the human immunodeficiency virus type 1 (HIV-1) transmembrane glycoprotein gp41 enhance HIV-1 infection in vitro. Proc Natl Acad Sci U S A 87(8):3185-3189

Rodenhuis-Zybert IA, Moesker B, da Silva Voorham JM, van der Ende-Metselaar H, Diamond MS, Wilschut J, Smit JM (2011) A fusion-loop antibody enhances the infectious properties of immature flavivirus particles. J Virol 85:11800-11808

Rolph MS, Zaid A, Rulli NE, Mahalingam S (2011) Downregulation of interferon- $\beta$ in antibodydependent enhancement of dengue viral infections of human macrophages is dependent on interleukin-6. J Infect Dis 204(3):489-491

Rothman AL (2011) Immunity to dengue virus: a tale of original antigenic sin and tropical cytokine storms. Nat Rev Immunol 11:532-543

Sangkawibha N, Rojanasuphot S, Ahandrik S, Viriyapongse S, Jatanasen S, Salitul V, Phanthumachinda B, Halstead SB (1984) Risk factors in dengue shock syndrome: a prospective epidemiologic study in Rayong, Thailand. I. the 1980 outbreak. Am J Epidemiol 120:653-669

Schmidt AC (2010) Response to dengue fever - the good, the bad, and the ugly? N Engl J Med 363(5):484-487

Serafin IL, Aaskov JG (2001) Identification of epitopes on the envelope (E) protein of dengue 2 and dengue 3 viruses using monoclonal antibodies. Arch Virol 146(12):2469-2479

Shanks GD, Burroughs SA, Sohn JD, Waters NC, Smith VF, Waller M, Brundage JF (2016) Enhanced risk of illness during the 1918 influenza pandemic after previous influenza-like illnesses in three military populations. Epidemiol Infect 144(10):2043-2048 
Shao W, Li X, Goraya ML, Wang S, Chen J-L (2017) Evolution of influenza A virus by mutation and re-assortment. Int J Mol Sci 18(8):E1650

Shi X, Deng Y, Wang H, Ji G, Tan W, Jiang T, Li X, Zhao H, Xia T, Meng Y et al (2016) A bispecific antibody effectively neutralizes all four serotypes of dengue virus by simultaneous blocking virus attachment and fusion. MAbs 8(3):574-584

Shmelkov E, Nadas A, Cardozo T (2014) Could vaccination with AIDSVAX immunogens have resulted in antibody dependent enhancement of HIV infection in human subjects? Hum Vaccin Immunother 10(10):3013-3016

Sholukh AM, Byrareddy SN, Shanmuganathan V, Hemashettar G, Lakhashe SK, Rasmussen RA, Watkins JD, Vyas HK, Thorat S, Brandstoetter T et al (2014) Passive immunization of macaques with polyclonal anti-SHIV IgG against a heterologous tier 2 SHIV: outcome depends on IgG dose. Retrovirology 11:8

Skowronski DM, De Serres G, Crowcroft NS, Janjua NZ, Boulianne N, Hottes TS, Rosella LC, Dickinson JA, Gilca R, Sethi P et al (2010) Association between the 2008-09 seasonal influenza vaccine and pandemic H1N1 illness during spring-summer 2009: four observational studies from Canada. PLoS Med 7(4):e1000258

Skowronski DM, Hamelin ME, De Serres G, Janjua NZ, Li G, Sabaiduc S, Bouhy X, Couture C, Leung A, Kobasa D (2014) Randomized controlled ferret study to assess the direct impact of 2008-09 trivalent inactivated influenza vaccine on A (H1N1)pdm09 disease risk. PLoS One 9:e86555

Smith SA, de Alwis AR, Kose N, Jadi RS, de Silva AM, Crowe JE (2014) Isolation of dengue virus-specific memory B cells with live virus antigen from human subjects following natural infection reveals the presence of diverse novel functional groups of antibody clones. J Virol 88(21):12233-12241

Sridhar S, Luedtke A, Langevin E, Zhu M, Bonaparte M, Machabert T, Savarino S, Zambrano B, Moureau A, Khromava A et al (2018) Effect of dengue serostatus on dengue vaccine safety and efficacy. N Engl J Med 379(4):327-340

Staprans SI, Barry AP, Silvestri G, Safrit JT, Kozyr N, Sumpter B, Nguyen H, McClure H, Montefiori D, Cohen JI et al (2004) Enhanced SIV replication and accelerated progression to AIDS in macaques primed to mount a CD4 T cell response to the SIV envelope protein. Proc Natl Acad Sci U S A 101(35):13026-13031

Subbramanian RA, Xu J, Toma E, Morisset R, Cohen EA, Menezes J, Ahmad A (2002) Comparison of human immunodeficiency virus (HIV)-specific infection-enhancing and -inhibiting antibodies in AIDS patients. J Clin Microbiol 40(6):2141-2146

Suhrbier A, La Linn M (2003) Suppression of antiviral responses by antibody-dependent enhancement of macrophage infection. Trends Immunol 24:165-168

Sullivan N, Sun Y, Binley J, Lee J, Barbas CF 3rd, Parren PW, Burton DR, Sodroski J (1998) Determinants of human immunodeficiency virus type 1 envelope glycoprotein activation by soluble CD4 and monoclonal antibodies. J Virol 72:6332-6338

Sun H, Chen Q, Lai H (2018) Development of antibody therapeutics against flaviviruses. Int J Mol Sci 19(1):E54

Szabo J, Prohaszka Z, Toth FD, Gyuris A, Segesdi J, Banhegyi D, Ujhelyi E, Minarovits J, Fust G (1999) Strong correlation between the complement-mediated antibody-dependent enhancement of HIV-1 infection and plasma viral load. AIDS 13:1841-1849

Takada A, Kawaoka Y (2003) Antibody-dependent enhancement of viral infection: molecular mechanisms and in vivo implications. Rev Med Virol 13(6):387-398

Takada A, Watanabe S, Okazaki K, Kida H, Kawaoka Y (2001) Infectivity-enhancing antibodies to Ebola virus glycoprotein. J Virol 75(5):2324-2330

Takada A, Feldmann H, Ksiazek TG, Kawaoka Y (2003) Antibody-dependent enhancement of Ebola virus infection. J Virol 77(13):7539-7544

Takada A, Ebihara H, Feldmann H, Geisbert TW, Kawaoka Y (2007) Epitopes required for antibody-dependent enhancement of Ebola virus infection. J Infect Dis 196(Suppl 2):S347-S356 
Takeda A, Tuazon CU, Ennis FA (1988) Antibody-enhanced infection by HIV-1 via Fc receptormediated entry. Science 242(4878):580-583

Takeda A, Sweet RW, Ennis FA (1990) Two receptors are required for antibody-dependent enhancement of human immunodeficiency virus type 1 infection: CD4 and Fc $\gamma$ R. J Virol 64(11):5605-5610

Tamura M, Webster RG, Ennis FA (1991) Antibodies to HA and NA augment uptake of influenza A viruses into cells via Fc receptor entry. Virology 182:211-219

Tamura M, Webster RG, Ennis FA (1994) Subtype cross-reactive, infection-enhancing antibody responses to influenza A viruses. J Virol 68(6):3499-3504

Tang C-T, Li P-C, Liu I-J, Liao M-Y, Chiu CY, Chao D-Y, Wu HC (2015) An epitope-substituted DNA vaccine improves safety and immunogenicity against dengue virus type 2. PLoS Negl Trop Dis 9(7):e0003903

Taylor A, Foo SS, Bruzzone R, Dinh LV, King NJ, Mahalingam S (2015) Fc receptors in antibodydependent enhancement of viral infections. Immunol Rev 268(1):340-364

TI-RS Group (1998) Palivizumab, a humanized respiratory syncytial virus monoclonal antibody, reduces hospitalization from respiratory syncytial virus infection in high-risk infants. Pediatrics 102(3 Pt 1):531-537

To KK, Zhang AJ, Hung IF, Xu T, Ip WC, Wong RT, Ng JC, Chan JF, Chan KH, Yuen KY (2012) High titer and avidity of nonneutralizing antibodies against influenza vaccine antigen are associated with severe influenza. Clin Vaccine Immunol 19(7):1012-1018

Toth FD, Szabo B, Ujhelyi E, Paloczi K, Horvath A, Fust G, Kiss J, Bánhegyi D, Hollán SR (1991) Neutralizing and complement-dependent enhancing antibodies in different stages of HIV infection. AIDS 5(3):263-268

Tóth FD, Mosborg-Petersen P, Kiss J, Aboagye-Mathiesen G, Zdravkovic M, Hager H, Aranyosi J, Lampé L, Ebbesen P (1994) Antibody-dependent enhancement of HIV-1 infection in human term syncytiotrophoblast cells cultured in vitro. Clin Exp Immunol 96(3):389-394

Trischmann H, Davis D, Lachmann PJ (1995) Lymphocytotropic strains of HIV type 1 when complexed with enhancing antibodies can infect macrophages via Fc gamma RIII. AIDS Res Hum Retrovir 11(3):343-352

Tsai T-T, Chuang Y-J, Lin Y-S, Chang C-P, Wan S-W, Lin S-H, Chen C-L, Lin C-F (2014) Antibody-dependent enhancement infection facilitates dengue virus-regulated signaling of IL-10 production in monocytes. PLoS Negl Trop Dis 8(11):e3320

Ubol S, Phuklia W, Kalayanarooj S, Modhiran N (2010) Mechanisms of immune evasion induced by a complex of dengue virus and preexisting enhancing antibodies. J Infect Dis 201:923-935

van de Winkel JG, Anderson CL (1991) Biology of human immunoglobulin G Fc receptors. J Leukoc Biol 49(5):511-524

van Erp EA, van Kasteren PB, Guichelaar T, Ahout IML, de Haan CAM, Luytjes W, Ferwerda G, Wicht $O$ (2017) In vitro enhancement of respiratory syncytial virus infection by maternal antibodies does not explain disease severity in infants. J Virol 91(21):e00851-e00817

van Mechelen L, Luytjes W, de Haan CA, Wicht O (2016) RSV neutralization by palivizumab, but not by monoclonal antibodies targeting other epitopes, is augmented by Fc gamma receptors. Antivir Res 132:1-5

Vaughn DW, Green S, Kalayanarooj S, Innis BL, Nimmannitya S, Suntayakorn S, Endy TP, Raengsakulrach B, Rothman AL, Ennis FA et al (2000) Dengue viraemia titer, antibody response pattern, and virus serotype correlate with disease severity. J Infect Dis 181(1):2-9

Villar L, Dayan GH, Arredondo-Garcia JL, Rivera DM, Cunha R, Deseda C, Reynales H, Costa MS, Morales-Ramírez JO, Carrasquilla G et al (2015) Efficacy of a tetravalent dengue vaccine in children in Latin America. N Engl J Med 372:113-123

Vogelpoel LT, Baeten DL, de Jong EC, den Dunnen J (2015) Control of cytokine production by human Fc gamma receptors: implications for pathogen defense and autoimmunity. Front Immunol 6:79

Wahala WM, Silva AM (2011) The human antibody response to dengue virus infection. Viruses 3(12):2374-2395 
Wang WK, Chen HL, Yang CF, Hsieh SC, Juan CC, Chang SM, Yu CC, Lin LH, Huang JH, King CC (2006) Slower rates of clearance of viral load and virus-containing immune complexes in patients with dengue hemorrhagic fever. Clin Infect Dis 43:1023-1030

Wang SF, Tseng SP, Yen CH, Yang JY, Tsao CH, Shen CW, Chen KH, Liu FT, Liu WT, Chen YM et al (2014) Antibody-dependent SARS coronavirus infection is mediated by antibodies against spike proteins. Biochem Biophys Res Commun 451:208-214

Wang Y, Si L, Luo Y, Guo X, Zhou J, Fang D, Yan H, Zeng G, Jiang L (2015) Replacement of pr gene with Japanese encephalitis virus pr using reverse genetics reduces antibody-dependent enhancement of dengue virus 2 infection. Appl Microbiol Biotechnol 99(22):9685-9698

Wang Q, Zhang L, Kuwahara K, Li L, Liu Z, Li T, Zhu H, Liu J, Xu Y, Xie J et al (2016) Immunodominant SARS coronavirus epitopes in humans elicited both enhancing and neutralizing effects on infection in non-human primates. ACS Infect Dis 2(5):361-376

WHO (2009) Dengue: guidelines for diagnosis, treatment, prevention and control. WHO, Geneva. www.who.int/tdr/publications/documents/dengue-diagnosis.pdf

Wilder-Smith A, Hombach J, Ferguson N, Selgelid M, O’Brien K, Vannice K, Barrett A, Ferdinand E, Flasche S, Guzman M et al (2019) Deliberations of the strategic advisory group of experts on immunization on the use of CYD-TDV dengue vaccine. Lancet Infect Dis 19(1):e31-e38

Willey S, Aasa-Chapman MM, O'Farrell S, Pellegrino P, Williams I, Weiss RA, Neil SJ (2011) Extensive complement-dependent enhancement of HIV-1 by autologous non-neutralising antibodies at early stages of infection. Retrovirology 8:16

Xu M, Zuest R, Velumani S, Tukijan F, Toh YX, Appanna R, Tan EY, Cerny D, MacAry P, Wang C et al (2017) A potent neutralizing antibody with therapeutic potential against all four serotypes of dengue virus. NPJ Vaccin 2:2

Yip MS, Leung NH, Cheung CY, Li PH, Lee HH, Daëron M, Peiris JS, Bruzzone R, Jaume M (2014) Antibody-dependent infection of human macrophages by severe acute respiratory syndrome coronavirus. Virol J 11:82

Yip MS, Leung HL, Li PH, Cheung CY, Dutry I, Li D, Daëron M, Bruzzone R, Peiris JS, Jaume M (2016) Antibody-dependent enhancement of SARS coronavirus infection and its role in the pathogenesis of SARS. Hong Kong Med J 22(3 Suppl 4):25-31

Zellweger RM, Prestwood TR, Shresta S (2010) Enhanced infection of liver sinusoidal endothelial cells in a mouse model of antibody-induced severe dengue disease. Cell Host Microbe 7:128-139

Zhang L, Zhang F, Yu W, He T, Yu J, Yi CE, Ba L, Li W, Farzan M, Chen Z et al (2006) Antibody responses against SARS coronavirus are correlated with disease outcome of infected individuals. J Med Virol 78:1-8 